Sonia González Molina, João Canavilhas, Miguel Carvajal Prieto,

Claudia Lerma Noriega y Tania Cobos Cobos

\title{
Hacia el Periodismo Móvil
}
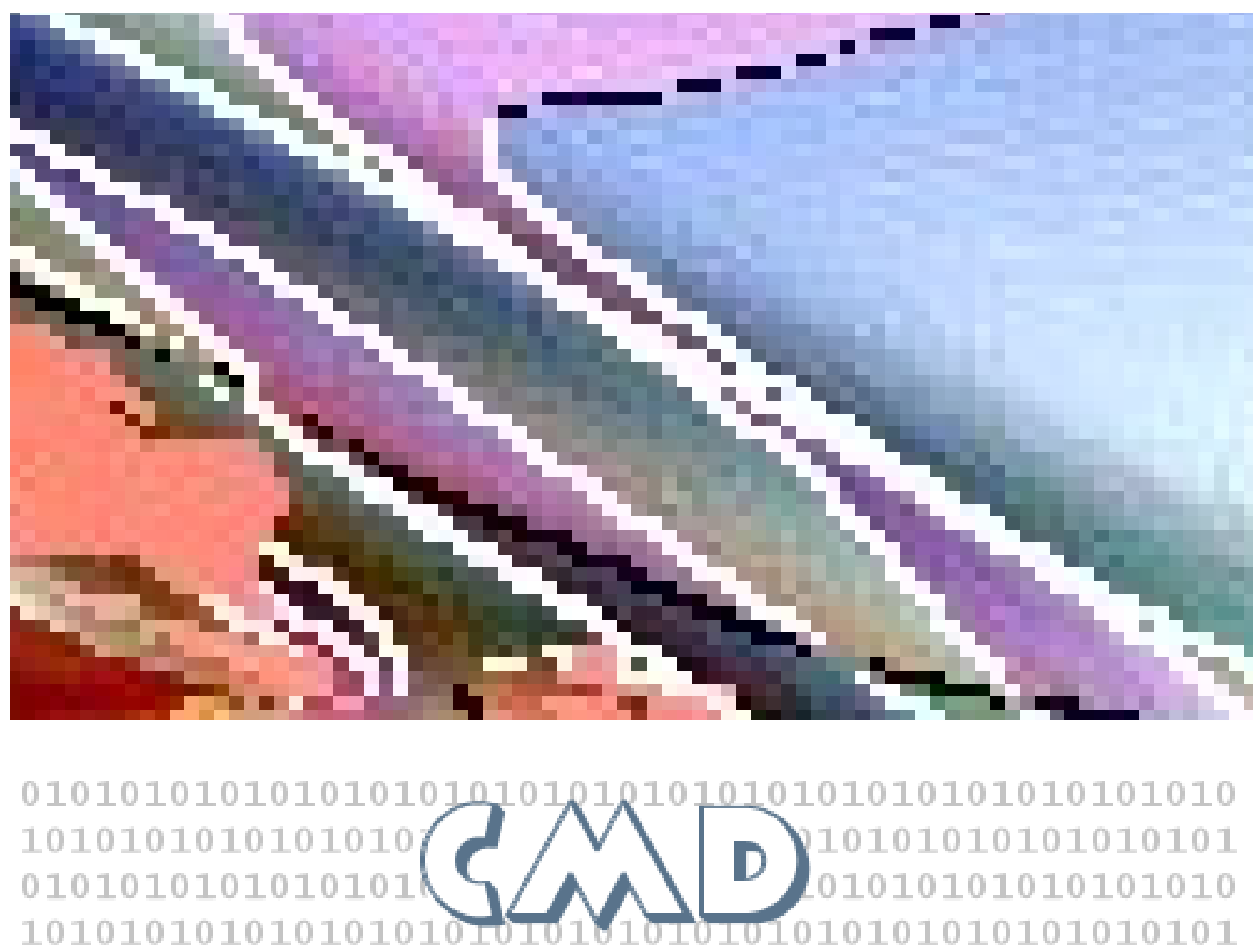

Colección Mundo Digital / 3

\section{Mediterránea \\ Comunicaciones 8


Hacia el Periodismo Móvil

Sonia González Molina, João Canavilhas, Miguel Carvajal, Claudia Lerma Noriega, Tania Cobos Cobos

Santiago de Chile, año 2013.

ISBN: 978-956-351-820-7

Editor del volúmen: Raymond Colle

Directora: Dra. Victoria Tur Viñes ("Revista Mediterránea de Comunicación”)

Coordinador de la Colección: Dr. Raymond Colle De S. (Portal "Comunicaciones Iberoamericanas")

Ilustración de portada: “ Pasarela05 ”, Transfoto R.Colle

Selecciona: Revista Mediterránea de Comunicación, Alicante (España)

(http://mediterranea-comunicacion.org/)

Difunde: Portal de "Comunicaciones Iberoamericanas" (Chile)

(http://comiber.recinet.org)

Con la participación y autorización de reproducción de la Sociedad Latina de Comunicación Social" y la colaboración de la red de "Investigadores e Investigaciones en Comunicación"”
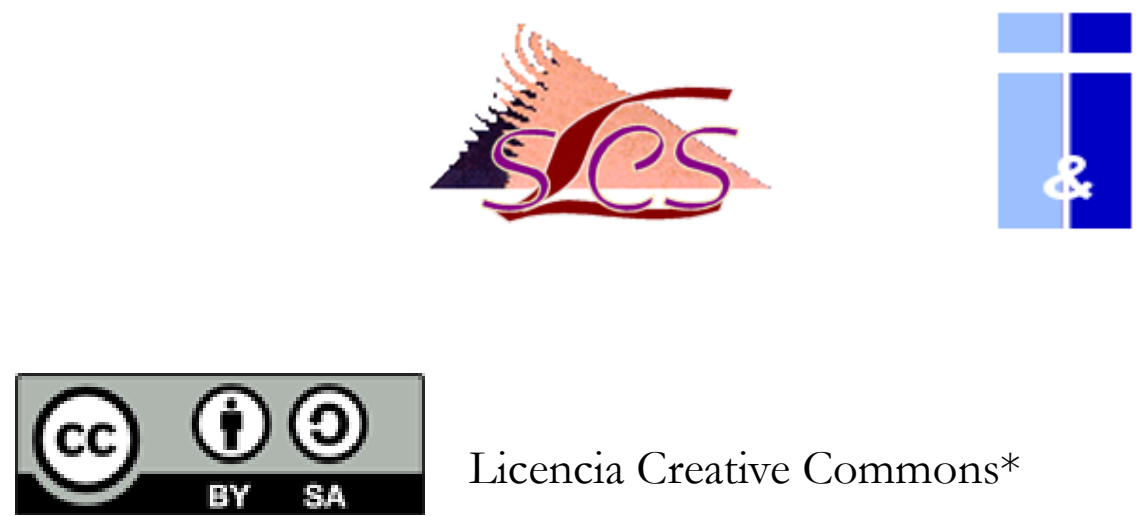

\section{Licencia Creative Commons*}

*Queda expresamente autorizada la reproducción total o parcial de los textos publicados en este libro, en cualquier formato o soporte imaginable, salvo por explícita voluntad en contra del autor o autora o en caso de ediciones con ánimo de lucro, señalando siempre la fuente. Las publicaciones donde se incluyan textos de esta publicación serán ediciones no comerciales y han de estar igualmente acogidas a Creative Commons. Harán constar esta licencia y el carácter no venal de la publicación.

1 http://www.revistalatinacs.org/12SLCS/portada2012.html

2 Http://investicom.recinet.org/ 


\section{Tabla}

Introducción, p.5

1. La polivalencia profesional de los periodistas en el entorno móvil (Sonia González Molina), p.7

1.1. Introducción, p.7

1.2. De profesional monomedia al periodista móvil, p.9

1.3. Configurando el periodista móvil, p.12

1.3.1. Fuentes activas y ubicuas, p.13

1.3.2. Hacia un ciclo de contenidos continuos, p.13

1.3.3. Lo social como rasgo informativo, p.14

1.4. Polivalencia en el entorno móvil, p.15

1.5. Conclusiones, p.16

1.6. Referencias bibliográficas, p.17

2. Modelos informativos para aparatos móviles: información hipermultimediática y personalizada (João Canavilhas), p.20

2.1. Introducción, p. 20

2.2. El teléfono móvil como objeto de uso cotidiano, p. 22

2.3. La cuarta pantalla y el periodismo, p.23

2.3.1. Teléfono móvil, p.24

2.3.2. Smartphones, p.25

2.3.3. Tabletas, p. 27

2.4. Los dispositivos móviles: la radio y la televisión, p.28

2.4.1. Teléfono móvil, p.28

2.4.2. Smartphones, p.29

2.4.3. Tabletas, p.29

2.5. Notas finales, p.29

2.6. Bibliografía, p.30

3. Estrategias de distribución del contenido periodístico en dispositivos móviles: Análisis comparativo de los principales editores de prensa española (Miguel Carvajal Prieto), p.33

3.1. Introducción, p.34

3.2. Objetivos, revisión bibliográfica y metodología, p.35

3.2.1 El análisis de las 4Cs, p.37

3.3. Resultados, p.39

3.3.1 Canal, p.39

3.3.2 Conversación, p.41

3.3.3 Contenido, p.41

3.3.4 Comercialización, p.42 
3.4. Conclusiones, p.43

3.5. Referencias bibliográficas, p.44

3.6. Anexos, p. 45

4. Desarrollo del Periodismo en Línea y Móvil en los diarios mexicanos (Claudia Lerma Noriega y Tania Cobos Cobos), p.50

4.1. Introducción, p.51

4.2. Plataformas digitales y desarrollo del Periodismo Móvil, p.51

4.3. Formatos del Periodismo Digital y Móvil, p.52

4.4. Propuestas de contenido para Periodismo Móvil, p.56

4.4.1. Alertas SMS, p. 57

4.4.2. Paso de portales WAP a portales móviles, p.58

4.4.3. Aplicaciones o apps, p.58

4.4.4. Edición para dispositivos digitales de lectura, p.59

4.4.5. Aspectos que configuran una aplicación noticiosa para móviles, p.61

4.5. Metodología, p.68

4.6. Hallazgos y reflexiones, p.69

4.7. Referencias bibliográficas, p. 71

Contraportada 


\section{(2) \\ Introducción}

Los años 2006 y 2007 marcaron un giro importante en materia de comunicaciones digitales, a diez años de la apertura de la Web al ámbito comercial y privado: se produjo el "despegue" de las redes sociales y, casi simultáneamente la comercialización de los llamados "teléfonos inteligentes" o "smartphones" que, poco a poco fueron incluyendo una cámara fotográfica. Hace ya años que la prensa se debate entre la forma impresa y la forma digital en la Web, debiendo ajustar su "modelo de negocio". Éste nuevo recurso está afectando ahora más directamente el trabajo de los periodistas tanto como el de los editores que se ven enfrantados a nuevas modalidades de lectura. Por ésto hemos recogido aquí algunos trabajos que dan cuenta de la nueva realidad.

En el primer capítulo, Sonia González aborda la forma en que se ven afectados los periodistas como consecuencia de la irrupción de los dispositivos móviles en su entorno de trabajo. Este nuevo escenario laboral introduce una serie de cambios en los procesos de producción, distribución y consumo informativos que implican nuevas habilidades profesionales

En el segundo capítulo, João Canavilhas trata las consecuencias del formato de recepción y discute las formas que permitan a las empresas periodísticas aprovechar el potencial de la "cuarta pantalla" en sus versiones smartphone y tableta. La aparición de Internet y de los dispositivos móviles con acceso a la Web abre la posibilidad de dar respuesta a diferentes segmentos de mercado, independientemente de su grado de interés en el tema. Para ello es necesario explorar las características técnicas de os teléfonos inteligentes y tabletas, creando lenguajes, formatos y nuevas posibilidades de liberar al lector para un consumo personal de noticias.

En el tercer capítulo, Miguel Carvajal nos describe como los smartphones afectan a los principales editores de la prensa española, a partir de un modelo de análisis en cuatro áreas (4Cs): canales, conversación, contenidos y comercialización. Los resultados de su indagación sugieren que la multiplicación de canales por ahora ha provocado una estrategia defensiva y que no se aprovechan los recursos de estos nuevos soportes, cada vez más importantes para la audiencia.

Finalmente, en el cuarto capítulo, Claudia Lerma recoge los resultados de dos diferentes observaciones al periodismo mexicano: una visualización de la implementación del periodismo digital en los diarios mexicanos y la adopción por ellos de las plataformas móviles, todo ello con el fin de visualizar el crecimiento que han presentado los diarios 
mexicanos en Internet, en algunos casos no solo para complementar las ediciones impresas, sino también como una opción para desarrollar el periodismo exclusivamente en línea.

Dr. Raymond Colle Coordinador de la Colección "Mundo Digital"

Tres de los capítulos de la presente obra corresponden a ponencias presentadas en el IV Congreso Latina de Comunicación Social que tuvo lugar en diciembre 2012 en la Universidad de La Laguna, Tenerife (España). Agradecemos tanto a sus autores como a los organizadores de dicho encuentro que autorizaron su publicación en el presente volúmen. El último capítulo ha sido proporcionado por dos investigadoras mexicanas que habían dado a conocer su trabajo en la red de "Investigadores e Investigaciones en Comunicación (I\&I). 


\title{
政
}

\section{La polivalencia profesional de los periodistas en el entorno móvil ${ }^{3}$}

\author{
Sonia González Molina \\ Universitat Jaume I, Castelló de la Plana, España
}

\begin{abstract}
Resumen
El perfil del periodista está en proceso de transformación como consecuencia de la irrupción de los dispositivos móviles en su entorno de trabajo. Este nuevo escenario laboral introduce una serie de cambios en los procesos de producción, distribución y consumo informativos que implican nuevas habilidades profesionales para a) gestionar las fuentes de información, b) elaborar contenidos periodísticos y c) relacionarse con una audiencia cada vez más participativa. Buena parte de estas transformaciones se pueden abordar desde el punto de vista teórico a partir de la noción de polivalencia. A partir de esta idea, esta propuesta plantea qué nuevas competencias deben atesorar los periodistas que trabajan en un contexto informativo marcado por la movilidad. Es decir, que se desarrolla bajo los parámetros de la instantaneidad, la ubicuidad, la personalización y la interactividad.
\end{abstract}

Palabras clave: Periodista móvil, polivalencia, convergencia, fuentes informativas, usergenerated content, smartphones, tablets.

\subsection{Introducción}

Toda innovación tecnológica que irrumpe en el sistema mediático tiene la capacidad de alternar el entorno en que el periodista ejerce su profesión. De este modo, cambia la forma en que este profesional produce las informaciones, se transforman los mecanismos las empresas informativas utilizan para distribuirlas y, por último, también evoluciona la manera en que el público se relaciona con estos contenidos. La irrupción de la tecnología digital en el ámbito de la comunicación ha contribuido a acelerar estos procesos, habitualmente enmarcados dentro de la etiqueta de convergencia. Por convergencia, aludimos a un proceso aún vigente que se inició a finales del siglo pasado y

3 Texto revisado de la ponencia de la autora presentada bajo el título "La transformación del perfil profesional del periodista ante el reto de la movilidad" en el IV Congreso Latina de Comunicación Social, Universidad de La Laguna, Tenerife (España), diciembre 2012. 
que introduce modificaciones de calado en las dimensiones tecnológica, empresarial, de contenidos y profesional de los medios de comunicación y sus trabajadores (Infotendencias group, 2012).

Precisamente esta última vertiente de la convergencia, la profesional, es la que se aborda bajo el epígrafe de polivalencia. Una noción que sirve para analizar todos aquellos cambios que ha experimentado ( $\mathrm{y}$ aún experimenta) el periodista en su perfil profesional desde el punto de vista de las funciones que desempeña, las habilidades y conocimientos técnicos que debe atesorar y la actualización continuada de estas competencias. Todo ello, para ejercer su profesión con estándares de calidad que marcan las nuevas exigencias de la digitalización. Del periodista que sólo se centra en elaborar una pieza informativa se está pasando cada vez más al profesional que también se ocupa de grabar los cortes de vOz o efectuar las fotografías del suceso. Los dispositivos móviles tipo smartphones y tablets vienen a añadir un elemento nuevo, el de la movilidad, con suficiente capacidad para transformar las competencias de los profesionales del periodismo. Los cambios que esta innovación tecnológica introduce tienen que ver con los mecanismos de producción, distribución y consumo informativo, ya que la movilidad, hábilmente combinada con las redes sociales, conlleva más accesibilidad, ubicuidad, personalización e identificación del medio y del dispositivo con el usuario (Aguado y Martínez, 2008).

Las cifras demuestran que el uso de este tipo de terminales está asentado. En Estados Unidos, el 52\% de los propietarios de un teléfono inteligente usan los smartphone para acceder a las noticias (Pew Research Center, 2012). Y, casi la mitad de europeos y norteamericanos posee un dispositivo de este tipo para acceder a internet (IAB, 2012). Por tanto, para el público, estas herramientas forman parte cada vez más de su día a día. Los periodistas no son ajenos a esta realidad y también para ellos las herramientas antes citadas se están convirtiendo poco a poco en un instrumento de trabajo habitual (Potter, 2013). Esta normalidad no enmascara los cambios que introducen en el sistema informativo, que se pueden sistematizar alrededor de tres ejes:

a. Se modifica el acceso a las fuentes, ya que aparecen nuevos actores con voz propia y capaces de incidir en el discurso informativo: el propio público, ubicuo y activo.

b. Se gana en rapidez y agilidad en las coberturas, que se pueden efectuar desde el mismo lugar en el que ocurren los hechos noticiosos incorporando a la vez la voz de la audiencia.

c. Se transforman los contenidos, que se tienen que adaptar al nuevo entorno de comunicación móvil que implica un continuo diálogo con el usuario, y la personalización y el servicio como exigencias ineludibles.

A partir de lo anteriormente expuesto, las próximas líneas exploran los cambios que experimenta el perfil profesional del periodista en el entorno móvil que contemple los aspectos anteriormente citados. Más concretamente, se busca detectar qué habilidades y capacidades necesita el profesional del periodismo para conseguir información, distribuir contenidos y relacionarse con la audiencia. El auge que actualmente experimenta el mercado de dispositivos móviles aconseja el abordaje académico de esta cuestión, máxime cuando la comunicación vive un momento convulso con los medios 
replanteándose su modelo de negocio (Casero-Ripollés, 2010). La oportunidad que este nuevo entorno representa para ellos (Aguado y Martínez, 2009) es clara y, de hecho, son los smartphones y las tablets los que impulsan el consumo de medios digitales en aquellos países que, como China, Brasil y Singapur, son líderes en este campo ${ }^{4}$. De ahí la conveniencia de realizar una aproximación a los cambios en las habilidades y capacidades del periodista ante el creciente uso de smartphones y tabletas en el algún momento de la fase de producción, distribución y consumo informativo.

\subsection{Del profesional monomedia al periodista móvil}

Cualquier innovación tecnológica implica una remodelación de las habilidades y conocimientos que deben atesorar los trabajadores para ejecutar sus funciones con normalidad. El mundo del periodismo no es ajeno a este fenómeno y, por ello, una de las esferas en las que el impulso transformador de la tecnología digital se ha dejado sentir con más fuerza tiene que ver con el perfil profesional del periodista, más concretamente con sus competencias. Los procesos de convergencia introducen cambios en este sentido al fomentar que los trabajadores desempeñen todo tipo de funciones dentro de las redacciones de los medios y cubran una gran variedad de temas. Unas actividades que antaño estaban asociadas a otros profesionales que únicamente se ocupaban de desempeñar una tarea. Esta realidad se concreta en el concepto de polivalencia, que alude a la capacidad y habilidad que tiene el periodista de ejercer simultáneamente diversos cometidos de forma habitual. Unos cometidos que van más allá de la simple recogida y elaboración de datos propia del periodista tradicional (Scolari et al, 2008). Abundando en esta idea, García Avilés et al. (2009) habla de profesionales polivalentes para referirse a aquellos que producen noticias para dos o más medios usando las herramientas tecnológicas pertinentes para cada estadio del proceso.

El concepto de periodista polivalente se empezó a configurar una vez que la tecnología digital irrumpió en el ámbito laboral del periodista. Rintala y Suolanen (2005: 57-58) identificaron las transformaciones más significativas que experimentaron los informadores como consecuencia de la convergencia, punto de partida de la polivalencia. A saber:

- La transferencia de tareas: Aquí las funciones que ejecuta un profesional determinado pasan a depender de otro.

- La fusión de roles tradicionales: Aquí un mismo trabajador efectúa las tareas de dos o más profesionales.

- El aumento de las funciones a asumir: Aquí el periodista se hace cargo de las nuevas actividades que aparecen vinculadas a los nuevos medios.

$4 \mathrm{El}$ dato proviene del informe de KPMG International 2013 Digital Debate The rise of the digital multitasker recogido por http://233grados.lainformación.com (consulta: 10 de febrero de 2013). 
Más allá de la desaparición de aquellos perfiles asociados a tareas obsoletas, esta nueva realidad implica una mayor polivalencia para los profesionales que permanecen al tener que hacerse cargo de nuevas actividades o de aquellas que desempeñaban otros compañeros. Es por ello que al periodista polivalente se le pide más flexibilidad y habilidades técnicas para trabajar en múltiples plataformas, con diferentes lenguajes y sobre diversos temas (Huang et al., 2006).

De lo anteriormente expuesto se deduce que existen diversos tipos de polivalencia. Micó (2006) distingue entre:

- Polivalencia mediática: El periodista produce contenidos para diferentes soportes. Sería el caso de un profesional que escribe para el diario y para la web del mismo medio.

- Polivalencia tecnológica: El periodista se hace cargo de todo o parte del proceso productivo. Sería el caso, por ejemplo, del profesional que produce y graba la pieza, o bien la edita.

- Polivalencia temática: El periodista cubre diversos ámbitos o secciones informativas. Se trata del periodista que elabora informaciones, de manera indistinta, para Sociedad, Política, etc.: una situación típica de los medios locales, de menor tamaño.

Para aquellos periodistas que ejercen su trabajo en los gabinetes de prensa o de comunicación, González Molina (2011) añade la polivalencia funcional, que se produce cuando estos profesionales suman a tareas propias del periodismo otras más cercanas a la publicidad y las relaciones públicas, como la organización de congresos, gestión del merchandising o de la publicidad institucional. De hecho, la polivalencia no es un rasgo exclusivo de los medios tradicionales, sino que también se encuentra en los departamentos de comunicación de empresas e instituciones y en las agencias de noticias (Gordillo y Nogué, 2008).

Con independencia de donde se desarrolle y del tipo que sea, la polivalencia no se muestra como un rasgo homogéneo sino al contrario. Depende de que la lógica de funcionamiento del medio en cuestión. Por ejemplo, Salaverría, García Avilés y Masip (2007) hablan tres grados progresivos de polivalencia (de menos a más) que van desde el periodista que trabaja sólo para un medio y realiza sólo una labor hasta el profesional que trabaja para diversas plataformas y ejecuta varias tareas. De la misma manera, Wallace (2013) habla, en este caso a partir de la experiencia de los trabajadores de la $\mathrm{BBC}$, de periodistas especializados (con habilidades estándar), polivalentes (que destacan por su versatilidad y capacidad de adaptación) y de periodistas multimedia (polivalentes sin perder la excelencia en su trabajo).

Este último apunte nos lleva a la cuestión de la calidad. Y es que la variedad de funciones y cometidos que lleva a cabo un profesional polivalente ha hecho que su figura se haya equiparado, en más de una ocasión, con la del periodista orquesta, capaz de cubrir un acto, hacer fotografías, grabar un vídeo, montarlo al llegar a la redacción y redactar piezas para varios soportes. Una práctica que se basaría en la idea errónea de que este trabajador 
debe ejecutar la misma o más tareas que un grupo de profesionales y que justificaría las reducciones de plantilla en los medios o la falta de calidad de algunas piezas. No obstante, también existe la realidad de las pequeñas emisoras y publicaciones, muchas de ellas locales, en la que la polivalencia no se concibe como una opción sino como una obligación ${ }^{5}$.

Como se ha explicado anteriormente, es posible distinguir diversos tipos de polivalencia. Una de ellas tiene que ver con los soportes informativos, de manera que el periodista es capaz de elaborar piezas para diversos medios como, por ejemplo, prensa o televisión e internet. Deuze (2004:140) habla de periodismo multimedia para aludir tanto a la publicación de noticias en internet usando dos o más formatos (texto, audiovisual, animaciones...) como a la distribución informativa integrada aunque no necesariamente simultánea a través de diversos medios (web, radio, correo electrónico, etc.).

El autor parte de la idea de convergencia, entendida como una confluencia de perfiles y espacios de trabajo, para ubicar al periodista multimedia en un contexto profesional marcado por el desarrollo del ciberperiodismo pero también por la creciente cooperación y colaboración de los diversos medios que integran un conglomerado de empresas periodísticas en el que se suceden prácticas como la promoción cruzada, la distribución cross-media o la integración total o parcial de redacciones.

La aparición y desarrollo de los dispositivos móviles introduce nuevos elementos en el escenario antes descrito al tratarse de un objeto cultural fuertemente ligado a la identidad del usuario pero también un medio para la producción, distribución y consumo de contenidos de todo tipo (Aguado y Martínez, 2008). Es su capacidad de unirse a internet lo que propicia la función informativa de estos terminales, ligados también al entretenimiento y al disfrute del ocio (Canavilhas, 2009), y lo que facilita su progresivo proceso de mediatización (Aguado y Martínez, 2006).

Es gracias a este proceso que se acaba de mencionar que el dispositivo móvil, como los smartphones o las tablets, se incorpora al sistema informativo y se pone a disposición del periodista para ejercer su trabajo. Una labor que ahora ha de tener en cuenta las propiedades que caracterizan a este tipo de terminales al menos desde los puntos de vista de la producción informativa, de la distribución de los contenidos y de la relación con la audiencia. Entre los rasgos de la información móvil a considerar en este sentido, Canavilhas (2011) destaca la individualización del consumo, la movilidad personal o el papel activo del público posible sobre todo gracias a la irrupción de los social media, que ha propiciado la aparición del Móvil 2.0 (Pardo, Brandt y Puerta, 2008; Aguado y Martínez, 2009).

La configuración de un entorno de trabajo móvil anima también la aparición de denominaciones para aludir al profesional que se desempeña en este entorno. Autores

5 Masip y Micó (2009) sistematizan las reservas que suscita el periodista polivalente desde los puntos de vista profesional y jurídicolaboral. Wallace (203) menciona al respecto el estrés que conlleva la polivalencia así como la posible merma en la calidad de las producciones. Como puntos positivos, la destaca la creatividad del relato. 
como Quinn (2009:10) hablan al respecto del periodista móvil o Mojo, contracción de los términos mobile journalist, que es el que usa principalmente el teléfono móvil como mecanismo para recopilar y distribuir noticias, ya sea en formato textual o audiovisual (sonido, imágenes fijas o en movimiento) o bien combinándolos. Se trataría de un periodista completamente desligado de los lugares físicos para preparar la noticia con la ayuda todo tipo de periféricos para enviar su pieza, que tendría como primer destino la web del medio (Cebrián Herreros y Flores Vivar, 2011: 221).

Para Canavilhas y Cavallari (2011), son seis los atributos que caracterizan estos contenidos periodísticos para plataformas móviles:

- Accesibilidad: la posibilidad de que los contenidos estén a disposición de la mayor cantidad de público posible.

- Instantaneidad: la capacidad de publicar al momento cualquier contenido periodístico

- Multimedialidad: la posibilidad de combinar texto, imagen y sonido en un mensaje o al menos dos de estos tres elementos.

- Hipertextualidad: la capacidad de ligar bloques de información, texto, imágenes y sonidos usando enlaces o links.

- Interactividad: la posibilidad que tiene el público para construir una relación con los contenidos informativos.

- Globalidad: la posibilidad de que los contenidos sean consumidos por cualquier persona en cualquier lugar.

La actual expansión de estos dispositivos hace que su uso sea cada vez más frecuente por lo que se impone abordar las transformaciones experimenta el perfil profesional de los informadores a partir de las nociones anteriormente expuestas.

\subsection{Configurando el periodista móvil}

Canavilhas (2011) analiza los cambios en el sistema informativo como consecuencia de la irrupción de los nuevos medios y los sistematiza alrededor de tres ejes. En este sentido, habla de un sistema push, en el que las noticias buscan a un público cada vez más autónomo a la hora de decidir cómo, cuándo y dónde las reciben; de una recepción heterogénea de los contenidos informativos como consecuencia de un consumo individual, continuo, móvil y global; y de un público interactivo, que colabora en la producción y redistribución de las informaciones a través de las redes sociales. A partir de estos tres ejes, relacionados entre sí, se sistematizan las transformaciones que experimenta el periodista en su trabajo como consecuencia de la irrupción de lo móvil en el entorno informativo. 


\subsubsection{Fuentes activas y ubicuas}

La principal transformación en este ámbito tiene que ver con la capacidad del usuario de elaborar materiales informativos que puede enviar a los medios de comunicación o distribuir por su cuenta que se ha identificado tradicionalmente con la noción de interactividad y participación de los usuarios. Ya en los primeros tiempos del periodismo en línea, se vio claro que internet facilitaba esto último gracias especialmente a la proliferación de blogs, foros de discusión y otras herramientas que, a la larga, se han acabado identificando con la web 2.0. Para los periodistas, este nuevo escenario significó al principio la posibilidad de acceder a nuevas fuentes, puntos de vista o testimonios, algunos de difícil acceso hasta el momento, con los que confeccionar sus noticias (Luzón, 2003). Son lo que Mencher (2000) identifica como fuentes en línea para diferenciarlas de las humanas y de las físicas.

El móvil no sólo recoge lo anteriormente expuesto sino que lo amplifica al facilitarle al usuario la producción de estos contenidos (textuales y audiovisuales, como fotografías o vídeos) a pie de calle y con el valor añadido de sus comentarios valorativos. La movilidad y la instantaneidad con que se pueden vehicular estos materiales aportan frescura informativa a las coberturas, que ganan en agilidad. Sin duda, las redes sociales contribuyen a acelerar estos procesos que se pueden abordar desde la óptica de los usergenerated-content (UGC) o contenidos generados por los usuarios.

Hermida y Thurman (2008) definen los UGC como un proceso en el que cualquier usuario puede contribuir en las publicaciones informativas profesionales. Se relaciona con el denominado periodismo ciudadano (Gillmor, 2004) y las prácticas de crowdsourcing o periodismo de fuentes masivas (Muthukumaraswamy, 2010), entendidos como mecanismos que facilitan la participación de la audiencia en espacios destinados inicialmente a los profesionales de la información (García-de-Torres, 2010).

Nada que objetar si se entiende esta posibilidad participativa como una fórmula para llegar a nuevas fuentes informativas, que tienen que ser tratadas con el mismo rigor y precauciones que con el resto. Es decir, verificando su origen y certeza y contrastando siempre la información facilitada, que puede estar viciada, ser tendenciosa o sólo reflejar un punto de vista interesado. Autores como Micó (2011: 207) alertan de que, muchas veces, detrás de estas fórmulas se esconden estrategias de fidelización empresarial por parte de los medios totalmente ajenas al propósito informativo. Extremar la prudencia, pues, es absolutamente necesario en un entorno móvil, en el que lo inmediato e instantáneo está a la orden del día.

\subsubsection{Hacia un ciclo de contenidos continuos}

A la hora de abordar la transformación de los contenidos distribuidos a través de estos dispositivos, es necesario recordar que el carácter móvil de este entorno facilita el consumo de la información en cualquier lugar y en cualquier momento, de manera rápida e instantánea. Para que estas propiedades no mermen la calidad de las producciones informativas de las plataformas móviles conviene tener en cuenta por un lado las características que deberían tener estos contenidos y, por otro, los rasgos del 
ciclo informativo que propicia este nuevo contexto.

Las reducidas dimensiones de las pantallas de los dispositivos móviles, de menor tamaño que un terminal fijo, inducen a producciones más breves, ya sean de naturaleza textual o audiovisual. Los mensajes de Twitter son un ejemplo claro de esta filosofía. La producción, gestión o adaptación de estos materiales para dispositivos móviles, asociados a las redes sociales, sería una labor nueva a tener en cuenta. Implicaría la redacción de textos cortos, sintéticos, directos. En el caso de incorporar algún vídeo, Quinn (2009) aconseja piezas de hasta 90 segundos y sin movimientos bruscos para facilitar un correcto visionado.

La ubicuidad de los contenidos móviles facilita la implantación de un ciclo continuo que obliga a plantear las coberturas integrando varias plataformas en función del momento informativo. El periodista que trabaja en un entorno móvil se perfila como el profesional adecuado para confeccionar noticias concebidas a modo de titulares o de típico flash de agencia, con sólo la información básica combinada a veces con una fotografía o un pequeño video. Una información que se actualiza al momento, a medida que se desarrolla el hecho noticioso, y que se puede tratar de manera más amplia y profunda en la redacción, según las características de cada medio: noticias en la web y en la radio, piezas más elaboradas para la televisión y reportajes interpretativos en el diario, por ejemplo.

Este esquema es fácilmente aplicable a aquellos hechos que necesitan de cierto tiempo para desarrollarse y que permiten un seguimiento continuado, a pie de calle, a modo de goteo informativo. La crónica encajaría a la perfección en este patrón, fácilmente extrapolable a otros contextos. Se trata aquí de construir un relato global a partir de tantos mensajes breves como novedades ocurran, acompañados de los recursos audiovisuales pertinentes (fotografías, vídeos o sonido). Fragmentos de síntesis y de consulta rápida que sólo a través de la acumulación permitirían configurar informaciones más amplias, contextualizadas y profundas (Cebrián Herreros y Flores Vivar, 2011: 144). Así, a través de Twitter se puede seguir la evolución del hecho al momento mientras que en el resto de plataformas se puede servir la información completa, con todos los datos debidamente contextualizados y con todos los recursos pertinentes. Esta manera de trabajar en el entorno móvil acerca el trabajo al ritmo de funcionamiento de una agencia de noticias.

\subsubsection{Lo social como rasgo informativo}

Ya se ha comentado que el entorno móvil facilita que el público se convierta en productor en sentido pleno hasta el punto de devenir una fuente de información útil para el periodista. Más allá del vínculo con el periodismo ciudadano o cívico, el crowdsourcing o el UGC, ya explicados, los usuarios participan del relato informativo enviando sus propuestas a los medios, explicando lo que ve o distribuyendo estos contenidos a través de sus perfiles públicos. El reto aquí consiste en incorporarlos al proceso noticioso de manera que enriquezca la visión del medio y doten de carácter social a las noticias (Cebrián Herreros y Flores Vivar, 2011: 222). 
Para ello es importante saber generar feedback, es decir, un correcto retorno a las aportaciones efectuadas por la audiencia como fórmula para aportar valor añadido a las informaciones así generadas. La interactividad adquiere así sentido pleno, al obligar al periodista a replantear su relación con un público más activo no sólo en la producción de contenidos sino también en su distribución a través de las redes sociales y otras herramientas 2.0.

Las características del contexto móvil, en el que la información fluye constantemente en forma de mensajes breves, conducen a una situación de sobreabundancia en el que el público no busca activamente la información sino que se la encuentra y la consume si se ajusta a sus intereses y necesidades. Una tendencia ya detectada en estudios que analizan el consumo informativo de los jóvenes que se efectúa principalmente a través de las redes sociales y que accederían a las noticias mientras navegan si les llaman la atención (Casero-Ripollés, 2012). Los nuevos servicios de geolocalización, que permiten recibir una información adecuada según las necesidades que tenga el usuario en cada momento y lugar, encajarían en este patrón.

Así pues, la relación con la audiencia también ha de contemplar la conveniencia de facilitarle contenidos que satisfagan sus exigencias, lo que implica una mayor adaptación de los mismos a sus gustos (Canavilhas, 2009). Canavilhas y Cavallari (2011) recuerdan al respecto la conveniencia de incluir links para permitir la máxima personalización de los contenidos y su contextualización a través de la bases de datos. La hipertextualidad facilita que los usuarios construyan su propio itinerario de consumo informativo y anima la interactividad entendida como una relación más personal entre el público y los contenidos que consume.

\subsection{Polivalencia en el entorno móvil}

Para Micó (2011: 204), el periodista que usa los dispositivos móviles como herramienta de trabajo es polivalente desde el punto de vista mediático, ya que elabora y distribuye contenidos para un soporte nuevo, y tecnológico, pues tiene que lidiar con una tecnología que afecta diversas etapas de la producción informativa. No habría ningún impedimento para el que periodista polivalente o el multimedia incorporen a su quehacer cotidiano la confección de piezas para este nuevo entorno o usen estos dispositivos para obtener o distribuir material informativo. En cualquier caso y según lo expuesto en los epígrafes anteriores, el periodista que trabaja en el entorno móvil a grandes rasgos debe aprender a:

- Saber producir material de todo tipo para ser distribuido por los dispositivos móviles e incluso saber adaptarlo a ellos si no ha sido producido originalmente para ellos. Las reducidas dimensiones de la pantalla y el hecho de ser consumidos en un entorno marcado por la movilidad, aconseja optar por contenidos (textuales 
o audiovisuales) breves, concisos y altamente personalizables.

- Saber gestionar la relación con el público que ahora puede usar los dispositivos móviles para producir y distribuir contenidos informativos propios y ajenos y valorar lo que pasa desde el lugar de los hechos. Se impone extremar la cautela para evitar informaciones poco contrastadas o tendenciosas en un contexto marcado por la instantaneidad y la participación continua.

- Saber detectar qué contenidos, materiales y recursos son susceptibles de ser distribuidos en el entorno móvil, con una dinámica más rápida, teniendo en cuenta que pueden ser ampliados posteriormente en otras plataformas asociadas al medio. Esto implica un trabajo de coordinación con el resto compañeros que colaboran con la cobertura informativa.

- Saber adaptarse a un ciclo de información continuo que implica ir facilitando de manera regular las novedades informativamente más significativas del hecho que se esté cubriendo. Se trata de una habilidad que implica saber seguir la evolución de un tema determinado de manera abierta. Sólo así se puede aprovechar la instantaneidad inherente al entorno móvil.

\subsection{Conclusiones}

Los cambios que introducen los dispositivos móviles en el entorno laboral del periodista suponen una serie de transformaciones en la manera en que se produce y distribuye la información que obliga a este profesional a cambiar sus habilidades. La polivalencia permite explicar estas mutaciones cuyo punto de partida es la adaptación a un entorno cada vez más descentralizado por la participación de la audiencia, que demanda más precisión y exigencia en la gestión de las fuentes, se mueve en la inmediatez y busca una mayor personalización y ubicuidad en los contenidos.

Al igual que las anteriores innovaciones que irrumpieron en el periodismo, los dispositivos móviles se están introduciendo con normalidad en el arsenal de herramientas a disposición de los informadores. Aunque su uso como soporte informativo es aún tímido, su progresiva extensión en el mercado obliga a plantearse de qué manera cambia la manera de trabajar de los periodistas que lo usan. Unos profesionales que desarrollarían su cometido principalmente a pie de calle, de manera individual y autónoma, que tendrían la suficiente habilidad como para suministrar datos de manera regular y continua, en formato textual y audiovisual e incorporando las aportaciones que al respecto pueda efectuar la audiencia. Un periodista, en fin, activo las 24 horas del día. 


\subsection{Referencias bibliográficas}

Aguado, J.M; Martínez, I.J. (2006). "El proceso de mediatización de la telefonía móvil: de la interacción al consumo cultural". Zer, núm. 20, pp. 319-343.

Aguado, J.M.; Martínez, I.J. (2008). "La cuarta pantalla: industrias culturales y contenido móvil”, en Aguado, J.M. y Martínez I.J. (Coords.) Sociedad móvil. Tecnología, identidad y cultura. Madrid: Biblioteca Nueva.

Aguado, J.M., Martínez, I.J. (2009). "De la Web social al Móvil 2.0: el paradigma 2.0 en el proceso de convergencia mediática de la comunicación móvil". El profesional de la información, vol. 18, núm. 2, pp.155-161. DOI: 10.314/epi.2009.mar.05.

Canavilhas, J. (2009). "Contenidos informativos para móviles: estudio de aplicaciones para iPhone”. Revista Textual \& Visual Media, núm. 2, pp. 61-80.

Canavilhas, J. (2011). "El nuevo ecosistema mediático". Index.comunicación, núm. 1, pp. 1324.

Canavilhas, J.; Cavallari, D. (2011). "Jornalismo para plataformas móveis de 2008 a 2011: da autonomía à emancipação". Líbero, vol. 14, núm, 28, pp. 53-66.

Casero-Ripollés, A. (2010). "Prensa en internet: nuevos modelos de negocio en el escenario de la convergencia". El profesional de la información, vol. 19, núm. 6, pp. 595-601. DOI: $10.3145 /$ epi.2010.nov05.

Casero-Ripollés, A. (2012). "Más allá de los diarios: el consumo de noticias de los jóvenes en la era digital". Comunicar, vol. 20, núm. 39, pp. 151-158. DOI: 10.3916/C392012-03-05.

Cebrián Herrreros, M.; Flores Vivar, J. (2011). Periodismo en la telefonía móvil. Madrid: Fragua.

Deuze, M. (2004). "What is Multimedia Journalism?”. Journalism Studies, vol. 5, núm. 2, pp.139-152.

García Avilés, J. et al. (2009). "Newsroom integration in Austria, Spain and Germany: Models of Media Convergence". Journalism Practice, vol 3, núm. 3, pp. 285-303.

García-de-Torres, E. (2010). "Contenido generado por el usuario: aproximación al estado de la cuestión”. El profesional de la información, vol. 19, núm. 6, pp. 585-594. DOI: 10.3145/epi.2010.nov.04.

Gillmor, D. (2004). We, the media. Grassroots journalism by the people, for the people. Schastopol: Ed. O'Reilly.

González Molina, S. (2011). La convergència en els gabinets de premsa i comunicación: Les oficines especialitzades en seguretat viària. Barcelona: Universitat Ramon Llull. Tesi doctoral.

Gordillo, S.; Nogué, A. (2008). "Agència Catalana de Notícies (ACN): model de periodisme multimèdia". Trípodos, núm. 23, pp. 49-59. 
Hermida, A; Thurman, N. (2008). "A clash of cultures. The integration of usergenerated content within professional journalistic framework at British newspaper websites”. Journalism practice, vol. 3, núm. 3, pp. 1-17.

Huang, E. et al (2006). "Converged Journalism and Quality: A Case Study on The Tampa Tribune News Stories". Convergence, vol. 12, núm.4, pp.73-91.

Infotendencias group (2012). "Media Convergence". Siapera, E.; Veglis, A. The Handbook of Global Online Journalism. Oxford: Wiley-Blackwell.

Interactive Advertising Bureau (IAB) (2012). Mediascope Europe 2012. Disponible en: http://www.iabeurope.eu/knowledge-bank/knowledge-bank/consumer-behaviour.aspx. [Consulta: 23 de agosto de 2012].

KPMG (2013). The rise of the digital multi-tasker (enero 2013). Resumen ejecutivo. Disponible en: http://www.kpmg.com/ES/es/ActualidadyNovedades/ArticulosyPublicaciones/Docu ments/Digital-Debate-2013.pdf [Consulta: 10 de febrero de 2013].

Luzón, V. (2003). Internet, l'eina inevitable. Periodistes, mitjans i missatges en xarxa. Barcelona: Col·legi de Periodistes, Diputació de Barcelona.

Masip, P.; Micó, J.L. (2009). "El periodista polivalent en el marc de la convergència empresarial". Quaderns del CAC, núm. 31-32, p. 85-92.

Mencher, M. (2000). News reporting and writing. Boston: MacGraw Hill.

Micó, J.L. (2011). "Periodistas audiovisuales inmóviles ante el periodismo multimedia móvil", en Casero Ripollés, A. y Marzal Felici, J. (eds.). Periodismo en televisión. Nuevos horizontes, nuevas tendencias. Sevilla, Salamanca, Zamora: Comunicación Social.

Micó, J.L. (2006). Periodisme a la xarxa: Llenguatge nou d'un ofici vell. Vic: Eumo.

Muthukumaraswamy, K. (2010). "When the media meet crowds of wisdom. How journalists are tapping into audience expertise and manpower for the processes of newsgathering"'. Journalism practice, vol. 4, núm.1, pp. 48-65.

Pardo, H., Brandt, J., Puerta, J.P. (2008). "Mobile Web 2.0. A Theoretical-Technical Framework and Developing Trends". International Journal of Interactive Mobile Technologies (iJIM), vol. 2, núm. 4, pp.54-61.

Pew Research Center (2012). The State of the Media. Disponible en: http://stateofthemedia.org/ [Consulta: 23 de agosto de 2012].

Potter, D.(2013). "IPhone reporting goes mainstream". Disponible en: http://www.newslab.org/2013/02/07/iphone-reporting-goes-mainstream// [Consulta: 10 de febrero de 2013].

Quinn, S. (2009). MoJo. Mobile Journalism in the Asian Region. Singapore: Konrad-AdenauerStiftung.

Rintala, N; Suolanen, S. (2005). "The Implications of Digitalization for Job Descriptions, 
Competencies and the Quality of Working Life”. Nordicom Review, vol. 26, núm. 2, pp. 5367.

Salaverría, R.; García Avilés, J.A.; Masip, P. (2007). "Convergencia periodística: propuesta de definición teórica y operativa”. Documento inédito desarrollado en el marco del proyecto "Convergencia digital en los medios de comunicación" (SEJ2006-14828-C06).

Scolari, C. et al (2008). "Nous perfils professionals i polivalencia del periodista a Catalunya: mapa de la situació". Quaderns del CAC, núm. 27, pp. 113-122.

Wallace, S. (2013). "The complexities of convergence: Multiskilled journalists working in BBC regional multimedia newsrooms". The International Communication Gazette, vol. 75, núm. 1, pp. 99-117.

* Esta propuesta forma parte del proyecto de investigación P1-1B2010-53, dirigido, como Investigador Principal, por Dr. Andreu Casero Ripollés (Universitat Jaume I), y financiado por la Fundació Caixa Castelló-Bancaixa y la Universitat Jaume I (Plan de Promoción de la Investigación, 2011-2013). 


\title{
2 \\ Modelos informativos para aparatos móviles: información hipermultimediática y personalizada $^{6}$
}

\author{
João Canavilhas \\ Universidade da Beira Interior, Portugal
}

\section{Resumen}

En las últimas décadas, los avances tecnológicos han permitido que las noticias lleguen más lejos, más rápido y a un público más amplio. Esta democratización en el acceso a las noticias tiene ventajas obvias, pero también algunas desventajas: la búsqueda de un lenguaje medio y de un conjunto de temas de interés corriente implica que el periodismo pierda alguna especificidad. Por otra parte, algunos medios buscan responder a nichos de mercado que prefieren la información especializada, pero estas publicaciones crean otro extremo: el de especialización excesiva.

La aparición de Internet y de los dispositivos móviles con acceso a la Web abre la posibilidad de dar respuesta a diferentes segmentos de mercado, independientemente de sus intereses. Para ello es necesario explorar las características técnicas de los teléfonos inteligentes y tabletas, creando lenguajes, formatos y nuevas posibilidades de liberar al lector a un consumo personal de noticias.

En este trabajo se discuten formas que permitan a las empresas periodísticas aprovechar el potencial de la cuarta pantalla (Aguado, 2008) en sus versiones smartphone y tableta.

Palabras-clave: tabletas, smartphones, periodismo.

\subsection{Introducción}

Pensado originalmente para que fuera una herramienta destinada a los decisores en las áreas de la economía y de la política, el teléfono móvil ha tenido un camino interesante

6 Ponencia del autor presentada en el IV Congreso Latina de Comunicación Social, Universidad de La Laguna, Tenerife (España), diciembre 2012 (traducida del portugués por el autor). 
rumbo a la masificación, hasta el punto de convertirse en un objeto de la vida cotidiana en todas las regiones del mundo.

De acuerdo con los datos de Gartner ${ }^{7}$, en 2012 las ventas de teléfonos móviles cayeron por primera vez en tres años y, aún así, de forma ligera. En comparación con otros sectores de la tecnología, la reducción de las ventas en un 3,1\% puede considerarse pequeña si tenemos en cuenta el escenario actual de la crisis global. Los resultados no fueron peores porque las ventas en el subgrupo de smartphones siguen subiendo y en 2012 han crecido un $45 \%{ }^{8}$ con relación al año anterior.

Estas cifras no hacen más que confirmar una trayectoria de gran éxito que transforma los teléfonos móviles en el medio que más rápidamente se masificó. Los números proporcionados por la UIT no dejan lugar a dudas: a finales de 2011 se calculaba que la tasa de penetración global de la telefonía móvil alcanzó el 86,7\%, cifra que es sustancialmente más alto que el 34,7\% de Internet y el 16,6\% de los teléfonos fijos.

En comparación con las cifras de otros medios de comunicación, el teléfono móvil sigue igualmente como vencedor: según el Tomi Ahonen Almanaque 2011, la tasa de penetración global de la radio fue de 56,3\%, la televisión de 23,1\% y la prensa diaria 6,5\%, todos valores mucho más bajos que los 86,7\% del teléfono. Además de esta impresionante tasa de penetración obtenida en corto tiempo, hay que señalar la distribución más homogénea de la telefonía móvil en todo el mundo, con todas las regiones del globo presentando valores superiores al 50\%.

En su versión más simple, los teléfonos móviles son un buen transmisor/receptor de noticias (voz o SMS), por lo que las empresas de telecomunicaciones ofrecen una multitud de servicios que permiten al usuario recibir desde resúmenes sonoros hasta cortas noticias textuales de último minuto. Con dispositivos más sofisticados, como los teléfonos inteligentes, las posibilidades de distribución de información son más variadas: la capacidad multimedia y la conexión a Internet abren un mundo de oportunidades que viene siendo bien recibido por los consumidores. Desde el lanzamiento del iPhone, en 2007, el mercado de los smartphones ha evolucionado muy rápidamente: los 143 millones de teléfonos inteligentes en todo el mundo en 2009, se elevó a 298 millones en 2010, 472 millones en 2011 y se esperan ventas de mil de millones en $2014^{9}$.

Después del éxito del iPhone, Apple lanzó el iPad, fundando un nuevo mercado: el de las tabletas. De acuerdo con Gartner ${ }^{10}$, en 2011 se vendieron 60 millones de unidades en todo el mundo, una cifra que se espera que aumente hasta los 119 millones en 2012 y aproximadamente 182 millones al año siguiente. El iPad lidera el mercado con un 68,2\% de los equipos en uso, seguido por Samsung con el 9,6\% y el Kindle Fire con un 5\%.

En paralelo con el lanzamiento del iPhone y del iPad, Apple dio un nuevo impulso a la iTunes Store, creando un prometedor mercado de aplicaciones (App Store) que se

7 http://www.gartner.com/newsroom/id/2237315

8 http://www.ucstrategies.com/unified-communications-newsroom/smartphone-sales-to-grow-by45-in-2012-idc-says.aspx

9 http://www.bgr.com/2012/04/13/smartphone-sales-estimated-to-surpass-1-billion-by-2014/

10 http://www.gartner.com/it/page.jsp?id=1980115 
convirtieron en una importante fuente de ingresos para varios tipos de negocios, incluyendo los periódicos, radios y televisiones de todo el mundo.

Este nuevo ecosistema mediático ubicuo y personalizado tiene un enorme potencial para el periodismo. Como receptor o como herramienta para los periodistas, el smartphone introduce cambios importantes en la actividad periodística, obligando a una reflexión sobre el tema. En este trabajo estudiaremos solamente la faceta del móvil como receptor de noticias.

\subsection{El teléfono móvil como objeto de uso cotidiano}

De mero dispositivo de telecomunicaciones dirigido a una élite, el teléfono móvil evolucionó al dispositivo multifunción que hoy conocemos y que acompaña cada día a más usuarios. Ningún otro objeto cotidiano pasa tanto tiempo con su propietario o tiene la misma proximidad. Este dispositivo se ha convertido en una especie de sexto sentido que añade al olfato, oído, visión, tacto y gusto una sensación de seguridad que resulta de poner nuestra geografía de amistades a la distancia de una llamada telefónica. Como destaca Vincent (cit in Dias 2008), el uso de un teléfono móvil exige más sentidos que cualquier otro medio de comunicación, ejerciendo por eso una gran atracción. Tal vez por ello, el teléfono se ha ganado un lugar central en nuestra vida personal y profesional, convirtiéndose en el lugar virtual que siempre acompaña a su usuario (Lasen, 2002), situación que permite estar siempre disponible para interactuar sea contactando a otros o por la disponibilidad para ser contactado. Esta ubicuidad y la fuerte conexión del dispositivo a la identidad de su propietario (Katz y Aarhus, 2002) son dos de los factores que ayudan a explicar el éxito de los teléfonos móviles. A estos dos factores se añade la libertad que ofrecen las capacidades comunicativas de los dispositivos: "In its mobilised version, communication is all about the fulfilment of an individual desire- a want. Being free to communicate is an aspect of getting what you want as much as possible" (Myerson, 2001, p.20).

La velocidad con la que estos dispositivos han evolucionado y se arraigaron en la sociedad es una consecuencia de cómo la tecnología y el usuario se influyen mutuamente: la existencia de los dispositivos ha creado una nueva demanda que al ser cada vez más exigente obligó a la tecnología a responder con nuevas posibilidades. Es decir, si inicialmente la oferta creó su propia demanda, esto también acabó condicionando la oferta, y por esto el mercado está en constante cambio: las empresas líderes en el pasado reciente, como Nokia o RIM (fabricante del BlackBerry), han dado lugar a Apple y Samsung, empresas que han logrado crear nuevas respuestas a las necesidades de los usuarios. A su vez, estas respuestas han traído más ofertas - como las aplicaciones - lo que acabó por crear una nueva necesidad y un nuevo mercado que puede ser la respuesta para algunos sectores en crisis, como el periodismo y la música, por ejemplo.

Las motivaciones para el uso móvil varían de un país a otro y entre generaciones, pero 
hay un conjunto que está identificado en varios estudios, independientemente de donde se haya efectuado. La posibilidad de estar en contacto con colegas, amigos y familiares (Ling, 2000; Höflich y Rossler, 2002; Aoki y Downes, 2003), mayor sensación de seguridad (Dimmick, Sikand y Patterson, 1994; Wilska, 2003; Kubik , 2009), la capacidad de enviar y recibir información de forma permanente, la movilidad y entretenimiento (Williams, Dordick y Jesuale, 1985; Höflich y Rossler, 2002) y el status social/sentido de pertenencia a un grupo (Leung y Wei, 2000; y Höflich Rossler, 2002; Taylor \& Harper, 2003) son algunas de las razones identificadas para una amplia gama de investigaciones que se llevaron a cabo en diversas partes del mundo con muestras de diferentes edades y estratos sociales. Este conjunto de estudios, junto con las tasas de penetración antes citadas, nos permiten decir con seguridad que los teléfonos móviles se han convertido en un fenómeno global y transversal.

Además de estas ventajas, el futuro parece igualmente garantizarse porque las bajas de precios de los equipos y la mejora de las capacidades multimedia han permitido a los jóvenes acceder a este tipo de tecnología. Esto se debe a que este grupo es particularmente sensible a las nuevas tecnologías, y también porque el teléfono móvil se ha convertido en una especie de vestimenta obligatoria entre los jóvenes (Cevallos, 2009). Es este interés que permite renovar la base de consumidores, lo que viene facilitando un crecimiento sostenido de las ventas, a pesar de la crisis.

\subsection{La cuarta pantalla y el periodismo}

La aparición de las tercera y cuarta pantallas (Aguado, 2008) obligó a los medios de comunicación a repensar sus estrategias de distribución. La posibilidad de llevar el contenido a los ordenadores, tabletas y teléfonos móviles abrió nuevos canales y creó la oportunidad para lanzar nuevos formatos periodísticos más atractivos y adaptados a usuarios cada vez más exigentes.

En el primer caso - la distribución - se cambió de un sistema pull (tirar) dónde el consumidor buscaba el contenido, a un sistema push (empujar) (Fidalgo \& Canavilhas, 2009) en el que son los contenido los que buscan al consumidor. Después de décadas en las que los medios de comunicación ocuparon el centro del sistema aprovechando el consumo grupal, el ecosistema mediático ha entrado en una nueva era caracterizada por el consumo individual y móvil, donde el usuario y la plataforma de acceso toman ese lugar céntrico. Esta individualización del consumo permite explorar la personalización de la información, ya que "a mobile telephone number is a code for direct access to one person" (Goodman, 2003, 13), una posibilidad que permite a los medios el desarrollo de una relación más cercana y de intimidad con su medio de comunicación preferido.

En el segundo caso - los nuevos formatos - aparecieron contenidos hipermultimediáticos e inmersivos (infografía interactiva, reportajes multimedia, serious games, etc) y se aceleró la velocidad de la información en circulación: las noticias de última hora, a 
menudo distribuidas por SMS, permiten al lector estar conectado de forma permanente a su realidad cercana por la posibilidad de recibir informes de noticias poco elaboradas y que pueden ser distribuidas inmediatamente después del suceso.

Las nuevas formas de distribución y los contenidos destinados a dispositivos móviles tienen muchas similitudes, pero los teléfonos móviles, los smartphones y las tabletas tienen distintas características técnicas y distintas formas de relacionarse con sus propietarios. Por lo tanto se debe evitar ahora un escenario similar al shovelware que caracterizó a los primeros años del periodismo en la web, y no caer en la tentación de distribuir el mismo contenido para las tres plataformas.

\subsubsection{Teléfono móvil}

El teléfono móvil simple (no smartphone) es el dispositivo de mayor difusión en este grupo de plataformas. Aunque los datos sobre el número de usuarios de teléfonos móviles que cambia muy a menudo, se estima que a finales de 2012 había en todo el mundo aproximadamente 6,6 mil millones de conexiones: se considera que el $10 \%$ está inactivo y cada usuario tiene un promedio de 1,8 SIM cards, por lo que existirían 3.2 mil millones de usuarios únicos ${ }^{11}$, la mayoría de los cuales tenía un aparato de este tipo. Como receptores de noticias, estos dispositivos pueden ser explotados en el formato más sencillo: el SMS (short message service). Por tener un coste muy bajo, que en algunas ofertas pude llegar a la gratuitidad, el formato es ampliamente utilizado por los jóvenes para intercambiar información. Los paquetes como los Moche (TMN), el Yorn (Vodafone) o Tag (Optimus) ofrecen mensajes gratis entre usuarios que pertenecen al grupo o red. Quizás debido a esto, un estudio realizado por Monit ${ }^{12}$ con estudiantes portugueses comprueba que este grupo envía un promedio de 100 SMS al día.

La cantidad de caracteres permitidos en este formato (160) y la facilidad con la que se pueden leer los mensajes transforman las SMS en un formato discreto que se adapta perfectamente a todos los entornos, incluyendo aquellos que requieren silencio. Por tanto, son un excelente canal para difundir información de última hora dirigida a todo tipo de público. Pero también son un medio eficaz para informar los jóvenes, un grupo que utiliza mucho este tipo de servicio. Además, por la facilidad de reenvío, los SMS tienen una naturaleza viral que puede facilitar la redistribución de la información entre usuarios.

El potencial de este tipo de mensajes no se agota en la velocidad de difusión. Tomando como referencia el News Diamond Model, de Paul Bradshaw (2007), la alerta es el primer paso en un proceso con dos variables: velocidad y profundidad. Esta perspectiva coincide con el concepto de formato evolutivo defendido por Canavilhas (2006) según el cual la noticia evoluciona desde este formato más simple ("alerta" para Bradshaw o "unidad de base" para Canavilhas) hasta formas más complejas producidos con recurso a

$11 \mathrm{https}$ ://wirelessintelligence.com/analysis/2012/10/global-mobile-penetration-subscribers-versusconnections/354/

12http://monit.it.pt/downloads/file177_pt.pdf 
bases datos para contextualización de la información. Debe destacarse aquí la importancia que puede tener este primer contacto con el usuario: cómo subrayan los dos autores, ser el primero en noticiar, aun que en este pequeño formato, lleva a que los lectores busquen actualizaciones de los acontecimientos en el sitio de la primera publicación que trató el tema (SMS - email - Twitter) o incluso en las versiones tradicionales de los medios. El uso del SMS puede ser el comienzo de un ciclo de consumo de noticias de gran valor para los medios y no sólo un formato para quien solamente quiere poca información.

\subsubsection{Smartphones}

Como se mencionó en los capítulos anteriores, el éxito de los smartphones está conectado a algunas de las características que comparte con los teléfonos móviles - como la portabilidad, la ubicuidad o la utilización personal - pero también está relacionada con las capacidades propias de estos mismos modelos, como la multimedialidad, la hipertextualidad y la interactividad facilitada por los altos niveles de usabilidad. A todo esto debe unirse la centralidad que el teléfono tiene la vida cotidiana de sus propietarios y que, en el caso de los teléfonos inteligentes, también se convirtió en un accesorio de moda (Ling, 1998 y 2004; Lasen, 2001). Esta asociación al fenómeno modal pone el teléfono móvil en un nivel diferente de lo que es ocupado por otras tecnologías, obligando el propietario a cambiar de equipo de acuerdo a los cortos ciclos de la moda.

El conjunto de características manifestado abre un amplio campo de posibilidades para las empresas periodísticas que deseen producir contenidos dirigidos a este segmento de mercado en acelerado crecimiento. En primer lugar, porque al ser un objeto de uso personal, el smartphone es también un canal de comunicación directa entre los medios de comunicación y los usuarios. Esta característica permite el suministro de información personalizada, una posibilidad con enorme potencial de monetización por la respuesta que puede dar a los nichos de mercado inalcanzables para los medios de comunicación de masas. Esta personalización puede utilizar algunas de las características únicas de este tipo de equipos que están relacionados con el lenguaje periodístico hipermultimediático.

Al igual de lo que ocurre en las computadoras, la hipertextualidad es una de las características fundamentales en los smartphones. La posibilidad de conectar bloques de información a través de enlaces permite al usuario hacer un consumo personalizado de noticias con un simple toque en la pantalla del dispositivo. Este poder que el usuario tiene para desencadenar una acción determinada en la plataforma - la interactividad - es otra característica clave.

A estas dos, comunes a computadoras y teléfonos inteligentes, podemos añadir una tercera característica: la multimedialidad. Si la lectura de textos largos puede ser un obstáculo debido a la pequeña dimensión de la pantalla, el sonido y el video tienen en estos dispositivos excelentes plataformas para un periodismo convergente más rico y variado mediante la incorporación de diferentes tipos de contenido en las noticias. Esta multimedialidad también puede ser un factor diferenciador en comparación con el webperiodismo: en lugar de recurrir a la convergencia de los contenidos -típico del 
periodismo en la web- en los smartphones se debe optar por la divergencia, con una distribución de contenidos únicamente textuales, video o sonoros, dependiendo del contexto en el que el usuario recibe la noticia.

Con esa finalidad pueden utilizarse dos elementos que tienen estos equipos: el receptor GPS y el acelerómetro. El primero indica la posición geográfica del dispositivo y la velocidad a la que se mueve, mientras que el segundo permite detectar movimiento del propio dispositivo, como la inclinación. El uso combinado del GPS y del acelerómetro puede utilizarse para un ajuste de la oferta de información al contexto geográfico y a la situación en que se encuentra el usuario. En primer lugar se da prioridad a las noticias de la zona donde está ubicado el receptor en ese momento (georeferenciación). En segundo lugar, y debido a que el dispositivo tiene la capacidad de reconocer que el usuario está en movimiento, se le puede dar la opción de recibir el contenido en forma de texto, video o audio: esto es lo que hemos llamado contenidos divergentes. Si el usuario va conduciendo, por ejemplo, no puede usar la visión, por lo que puede optar por escuchar las noticias, eligiendo el formato de audio. Estaríamos así ante la necesidad de que cada medio de comunicación produjera sus historias en tres formatos -texto, sonido y video y seria el dispositivo o su titular a elegir el formato que mejor se adapte a su contexto momentáneo: sonido para situaciones en las que el usuario está realizando otra actividad, video o texto para ambientes tranquilos cuando hay plena disponibilidad.

El uso simultáneo de GPS, conectividad a Internet y cámara de vídeo también permite a los smartphones la exploración de otras tecnologías con gran potencial para el periodismo. Este es el caso de la realidad aumentada, que permite la interacción de objetos reales con objetos virtuales. Aparte de su uso en el campo del entretenimiento y de la publicidad, la prensa puede utilizarla para reconstruir espacios y eventos, transportando el usuario a un escenario pasado o futuro. Imaginemos, por ejemplo, que la noticia busca explicar una intervención urbana en un determinado local: el lector sólo tiene que direccionar la cámara de su smartphone al lugar para tener un avance de cómo va a quedar ese espacio.

El uso de estas capacidades permite un periodismo más contextualizado que incluye " not only the multimedia capabilities of digital platforms but also the interactive bypermedia, fluid qualities of online communications and the customizable features of addressable media" (Pavlik, 2001, p. 218). En cierto modo, este periodismo contextualizado es el máximo grado de personalización. Por un lado, la hipertextualidad y la interactividad permiten la libre navegación. Por otro, la multimedialidad, el GPS y el acelerómetro facilitan al usuario recibir la información en el formato más adecuado para el lugar y la situación en la que está en ese momento

Además de su lado informativo, los teléfonos inteligentes son también plataformas con un gran potencial para explorar nuevas formas de publicidad, que es una parte integral del negocio de la comunicación social. Un ejemplo sencillo de este potencial puede ser la combinación del uso del GPS, del acelerómetro, del reloj y de una aplicación nativa (app). Sintiendo que un usuario se desplaza entre el lugar donde vive y otro punto distante, la aplicación puede enviar sugerencias de restaurantes a la hora de comer. En el 
caso de un usuario de Foursquare que suele hacer check-ins en un tipo específico de restaurantes -pizzerías, por ejemplo- la primera sugerencia sería de restaurantes italianos en la zona. También es posible sugerir lugares para visitar y usar la realidad aumentada para anticipar información sobre el lugar.

Por último, destacar que hay una amplia gama de posibilidades que se pueden explorar en las narrativas transmedia, utilizando el móvil con uno de los elementos de la cadena. Mientras objeto personal, el smartphone es la plataforma ideal para mantener una conexión permanente del usuario a las noticias en actualización, permitiendo además su participación mediante el envío de informaciones u opiniones que son inmediatamente incorporados en las noticias

\subsubsection{Tabletas}

A pesar de las grandes similitudes técnicas entre estos dispositivos y los teléfonos inteligentes, la diferencia de tamaños de pantalla está causando cierta incertidumbre en los modelos noticias destinadas a estos dispositivos. Dos años después de haber creado este nuevo mercado, Apple sigue liderando las ventas con su iPad (9,7 pulgadas), pero hay otros dispositivos en el mercado cuyas pantallas varían entre 7 y 10,1 pulgadas. Incluso en las dimensiones mínimas, las tabletas están lejos de permitir la estrecha relación que los teléfonos inteligentes tienen con sus usuarios. En este aspecto, su relación con el propietario está más cerca de la computadora personal, pero con una mejor portabilidad. Por esta razón, las versiones de periódicos para tabletas han probado varios modelos siguiendo las diferentes perspectivas que las empresas tienen estos dispositivos.

En algunos casos los modelos se acercan a la prensa en papel. Esta similitud es una estrategia de periódicos que buscan revitalizar los periódicos de la tarde. En la edición de 2012 del International Symposium on Online Journalism, en Austin, Pedro Doria, director de la plataforma digital del diario brasileño O Globo, sostuvo que las tabletas se destinan principalmente al consumidor que quiere la información actualizada al final del día y, si es posible, enriquecida con algunos contenidos multimedia. En este caso, las versiones para tabletas serian una actualización de las ediciones matutinas de papel, con mayor componente de vídeo y sonido, un modelo que también defendió Busswood (2010). En cuanto a la facilidad de uso, Mario García ${ }^{13}$ refiere que la información para tabletas debe desviarse del modelo de la impresión en papel, sugiriendo un diseño disruptivo. En la evaluación de la aplicación del Denver Post, que sigue un modelo similar al de Flipboard, García destaca la existencia de dos "páginas de bienvenida", una de los cuales tiene únicamente imágenes y títulos, lo que da una idea inmediata de los temas destacados, no imitando a los periódicos. Esta forma alternativa de presentación de las noticias es una de las hipótesis de diferenciación, pero hay muchas otras alternativas.

En este caso hablamos de un modelo de información complementaria a la prensa que podemos llamar "Modelo Complemento" y que consiste en una distribución vespertina

13http://www.garciamedia.com/blog/articles/new ipad edition for the denver_post_a great_start 
de las noticias publicadas en los periódicos de la mañana, pero con los nuevos desarrollos, textos de opinión para enmarcar evento, un fuerte componente multimedia interactivo y un diseño adaptado a la plataforma.

Una segunda versión, esta más cercana al modelo del smartphone, pasaría por distribución de contenidos poco complejos -noticias de última hora- que buscan sobretodo mantener al lector informado, aunque con poca profundidad. En este modelo de noticias, la mayor dificultad es la diferenciación de la competencia, que sólo puede darse en dos campos: la velocidad y la usabilidad. En este " Modelo de Agencia", la mayor preocupación es ser el primero en informar y organizar todas las novedades para que el lector pueda seguir los temas de una forma intuitiva y con unos pocos clics. Este modelo no favorece la opinión o la multimedialidad, pero lo que Groth (Fidalgo, 2004) llama actualidad, es decir, algo que ocurre en el momento presente, mirando hacia la simultaneidad entre el acontecimiento y su divulgación. Más allá de la actualidad, el "Modelo de Agencia" puede explorar la geolocalización para proporcionar la información de contexto al usuario, en este caso contexto geográfico.

Por último, una tercera versión que puede ser la utilización de las tabletas como ereader para distribución de las versiones tradicionales en formato PDF, ePub, etc. Aquí hay tres ventajas: facilidad de manejo del periódico, en un modelo cercano al de las revistas; un sistema de retro iluminación que permite leer en cualquier entorno y distribución global, donde hay un punto de acceso a Internet para descargar el periódico. En este caso hablamos de un "Modelo Soporte" en el que las características de los contenidos distribuidos son los mismos que el original, sólo cambiando la forma como el periódico llega al lector y la forma como lo maneja. De los tres modelos, este es el que menos explora el potencial hipermultimediático del dispositivo, pero aún así este uso simple puede representar un valor añadido para los usuarios ya que, además de las ventajas mencionadas, los abonos de las versiones de PDF son más baratos.

\subsection{Los dispositivos móviles: la radio y la televisión}

En el apartado anterior hemos abordado las ventajas y desventajas de los teléfonos móviles, teléfonos inteligentes y tabletas para la prensa. El mayor énfasis a este medio está relacionado con el hecho de que es el que puede ganar más con la distribución de estas plataformas, pero también hay ventajas para la radio y la televisión.

\subsubsection{Teléfono móvil}

En el caso de la radio, los teléfonos móviles pueden actuar como receptor de las emisiones hertzianas. Las similitudes entre la vieja radio de baterías y los teléfonos móviles son, de hecho, evidentes: hablamos de dos dispositivos de uso personal y pequeñas dimensiones que acompañan permanentemente a sus usuarios, aunque el teléfono esté más transversal a todas las generaciones y la radio se utiliza sobre todo por 
los mayores. Los teléfonos móviles también se pueden utilizar como receptores de noticias a través de SMS, tal como en la prensa, funcionando aquí como un complemento a las emisiones de radio tradicionales

\subsubsection{Smartphones}

En este caso, además de la tradicional recepción hertziana, existe igualmente la posibilidad de acceder a millones de emisiones de radio en Internet. El gran inconveniente es que el acceso por IP es una opción costosa cuando el receptor está fuera de las zonas $\mathrm{WiFi}$. En el caso de la televisión la situación es aún peor porque el consumo de datos dispara. Además, el hecho de que la pantalla sea muy pequeña dificulta la visualización de determinado tipo de contenidos.

En pocas palabras, y mirando sólo a su uso fuera de zonas wi-fi, podemos decir que los teléfonos inteligentes pueden ser utilizados principalmente para noticias de última hora, en un "Modelo de Agencia" similar al propuesto para los periódicos. A través de push alerts, radios y televisiones pueden disfrutar de la proximidad del dispositivo a su usuario para atraer a los consumidores, prometiendo avances de noticias en sus versiones tradicionales. También puede explorar la geolocalización, como en los periódicos, y el consumo diferido, con podcast y videocast.

\subsubsection{Tabletas}

Las ventajas de la radio se encuentran principalmente en el nivel de acceso a las versiones Web, particularmente aquellos que ofrecen contenidos multimedia tales como vídeo e infografías. Esta situación se repite en el caso de la televisión, pero en este caso con las ventajas de que este dispositivo tiene una pantalla que permite una cómoda visualización de contenido video. En emisión videocast o directa, las tabletas son excelentes plataformas para hacer más televisión móvil.

\subsection{Notas finales}

En un momento en que las empresas de comunicación cruzan una de las peores crisis de siempre, el actual aumento de las tasas de penetración de los teléfonos inteligentes y de las tabletas puede establecerse como una fuente de ingresos alternativa. La posibilidad de ofrecer información hipermultimediática, contextualizada y personalizada responde a las preocupaciones expresadas por los lectores cuando se les pregunta qué les haría pagar la información online. Es, por ello, una oportunidad para que las empresas puedan cobrar por el acceso a las noticias.

En primer lugar, el vínculo entre el usuario y el dispositivo crea una relación de proximidad única y distintiva. Ningún otro medio tiene la distinción de ser precedido por un pronombre posesivo cuando un usuario se refiere a él, preguntando: "¿has visto mi teléfono?" Es muy diferente a preguntar "¿dónde está el periódico" o "te gusta nuestro 
nuevo televisor?". La relación es de tal forma personalizada que el dispositivo se convierte en un tipo de dirección privada, creando un canal de comunicación personal entre su propietario y el mundo. En el caso de los smartphones, el privilegio de tener un canal dedicado permite a los usuarios filtrar la información de prioridad, al programar el dispositivo para recibir sólo la información que le interesa a través de sistemas push.

La fuerte conexión entre dispositivo y usuario -en contacto físico durante la mayor parte del día- también permite personalizar la información en función del contexto geográfico y social: las características técnicas de estos dispositivos permiten la distribución de contenidos de interés en el sitio donde está el usuario, y puede ser distribuido en formatos (texto, sonido, vídeo) más apropiado a la situación. Las posibilidades de combinar estas opciones con contenidos hipermultimediáticos inmersivos son tan grandes que se puede encontrar un sinfín de maneras para ofrecer información personalizada.

La información personalizada es, sin duda, la gran marca distintiva de periodismo para dispositivos móviles. Distribuir la información a una plataforma personal que acompaña continuamente su propietario es una ventaja sobre todos los demás medios, pero hay que saber aprovechar este privilegio ofreciendo información única. Más que canales y publicaciones especializadas -que se limitan a hacer una segmentación del mercado- los smartphones y las tabletas tienen la capacidad de recibir información hipertextual y multimedia, además de que cuentan con tecnologías que permiten reconocer su ubicación y cómo se mueven. Esta combinación de capacidades permite segmentar las noticias hasta el punto de que sean únicas para el usuario. $\mathrm{Y}$ esto es precisamente el valor-añadido que puede transformar el producto más atractivo para los consumidores, a punto de que disponibilize para pagar los contenidos, generando los ingresos que ahora mismo necesita el periodismo digital.

\subsection{Bibliografía}

Aguado, J.M. \& Martínez, I.J. (2008). Sociedad Móvil: tecnología, identidad y Cultura. Madrid: Edit. Biblioteca Nueva.

Aguado J.M. \& Martínez. I. J (2012). El medio Líquido: la comunicación móvil en la sociedad de la información. En Francisco Sierra, Francisco Javier Moreno y Carlos del Valle Rojas, Políticas de Comunicación y ciudadanía cultural iberoamericana, pp. 119175.

Aoki, K. \& Downes, E. J. (2003). An analysis of young people's use of and attitudes toward cell phones, Telematics and Informatics, Vol. 20, No. 4, pp. 349-364.

Busswood , P.(2010). News 2.0: How newspapers can survive by embracing technological innovation? Capilano Undergraduate Review, $\mathrm{n}^{\circ}$ 1, mayo, pp. 3-8.

Bardoel, J. \& Deuze M. (2001). Network Journalism: Converging Competences Of Old 
and New Media professionals. Recuperado el 15 de mayo de 2011 desde https://scholarworks.iu.edu/dspace/handle/2022/3201.

Bolter, J.D. \& Grusin, R. (1999). Remediation. Understanding New Media. Cambridge: The MIT Press.

Bradshaw, P. (2007). A model to the 21st century newsroom: PT1 . The news diamond. Acedido no dia 9 de Julho de 2012 em http:/ / onlinejournalismblog.com/2007/09/17/amodel-for-the-21st-century-newsroom-pt1-the-news-diamond/

Canavilhas, J. (2009). Contenidos informativos para móviles: estudio de aplicaciones para iPhone. Revista Textual \& Visual Media, 2, p.61-80. Madrid.

Cevallos, M. del C. (2009). Jóvenes y celulares: las razones de su uso y abuso. Acedido no dia 2 de maio de 2012 http://www.ciespal.net/ciespal/images/docu/produccionacademica/Informe $\% 20$ celulares.pdf

Dias, P. (2008). O telemóvel e o quotidiano. Lisboa: Paulus Editora

Dimmick, J.W., Sikand, J. y Patterson, S. J. (1994). The Gratifications of the Household Telephone: Sociability, Instrumentality and Ressurance. Communication Research, 21(5), pp. 643-663.

Dupagne, M.\& Garrison, B. (2006). The meaning and influence of convergence. Journalism Studies, Volume 7, N.2, pp. 237-255.

Fidalgo, A. (2004). Jornalismo Online segundo o modelo de Otto Groth. Acedido no dia 15 de agosto de $2012 \mathrm{em} \mathrm{http://www.bocc.ubi.pt/pag/fidalgo-groth-jornalismo-}$ online.html

Fidalgo, A. \& Canavilhas, J. (2009). Todos os jornais no bolso: Pensando o jornalismo na era do celular. En Carla Rodrigues (Org.). Jornalismo On-Line: modos de fazer , pp. 96146.

Fidler, R. (1997). Mediamorphosis: Understandig New Media.Thousand Oaks: Pine Forge Press.

Goodman, J. (2003). Mobile telephones and social capital in Poland: A case study with Vodafone Group. Acedido no dia 3 de julho de $2012 \mathrm{em}$ https://www.forumforthefuture.org/sites/default/files/project/downloads/mobilephones-and-social-capital-case-study.pdf

Hoflich, J. \& Rossler, P. (2002). Más que un Teléfono: el teléfono móvil y el uso del SMS por parte de los adolescentes alemanes - resultados de un estudio piloto. Revista de Estudios de Juventud, 57, pp. 79-100.

Katz, E. \& Aarhus, M. (2002). Perpetual Contact: Mobile Communication, Private Talk, Public Performance. Cambridge. Cambridge University Press.

Kubik S. (2009). Motivations for cell phone use by older Americans. Gerontechnology, Vol 8, 3, pp.150-164 
Lasen, A.(2002). A Comparative Study of Mobile Phones Use in Public Places in London, Madrid and Paris. Acedido no dia 2 de maio de $2012 \mathrm{em}$ http:// ronik7.files.wordpress.com/2010/01/compstudy.pdf

Leung, L., \& Wei, R. (2000). More than just talk on the move: Uses and gratifications of the cellular phone. Journalism and Mass Communication Quarterly, Vol. 77, No. 2, p. 308-320

Ling, R. (1998). One can talk about Common Manners! The Use of Mobile Telephones in Inappropriate Situations. Em L. Haddon (ed.) Communications on the Move: The Experience of Mobile Telephony in the 1990s, COST248 Report, Telia, Farsta.

Ling, R. (2000). We will be reached: the use of mobile telephony among Norwegian youth. Information Technology \& People, Vol. 13, No 2, pp.102-120

Ling, R. (2004). The mobile connection: the cell phone's impact on society. San Francisco: Elsevier

Myerson, G. (2001). Heidegger, Habermas and the Mobile Phone. Cambridge: Icon Books Ltd.

Pavlik, J. (2001). Journalism and New Media. Columbia: Columbia University Press.

Sundet, V. S. \& Espen , Y. (2009). Working Notions of Active Audiences: Further Research on the Active Participant in Convergent Media Industries. Convergence: The International Journal of Research into New Media Technologies, November, 15, pp: 383-390.

Taylor, A., \& Harper, R. (2003). The gift of the gab? A design orientated sociology of young people's use of mobiles. Computer Supported Cooperative Work, Vol. 12, pp. 267-296.

Williams, F., Dordick, H. \& Jesuale, H. (1985). Focus Group and Questionnaire Development for Exploring Attitudes Towards Telephone Service. En F. Williams (edit): Social Research and the Telephone. Los Angeles (CA): Herbert Dordick and Associates.

Wilska, T.A. (2003). Mobile phone use as part of young people's consumption styles. Journal of Consumer Policy, Vol. 26, No. 4, p. 441. 


\title{
b
}

\section{Estrategias de distribución del contenido periodístico en soportes móviles:}

\section{Análisis comparativo de los principales editores de prensa española ${ }^{14}$}

\author{
Miguel Carvajal Prieto \\ Universidad Miguel Hernández, Alicante, España
}

\section{Resumen}

La penetración de smartphones y tabletas digitales y el consecuente aumento del consumo de noticias en soportes móviles es una realidad para la industria de la comunicación. Los editores de prensa, con enormes dificultades para salvar su modelo de negocio impreso, afrontan ahora otro reto. El auge de las redes sociales y la convergencia multiplaforma inciden en la fragmentación del consumo de información. Con la aparición de nuevas ventanas para distribuir el contenido periodístico, los medios afrontan la renovación de sus modelos con la esperanza de recuperar el terreno perdido en la economía de la atención.

Este trabajo forma parte de un proyecto de investigación global que pretende analizar las estrategias de producto y de distribución de los medios de comunicación en el ámbito digital. El objetivo de esta comunicación es describir la presencia de los principales editores de prensa española en los móviles y en las tabletas a partir de un modelo de análisis en cuatro áreas (4Cs): canales, conversación, contenidos y comercialización. Los resultados sugieren que la multiplicación de canales por ahora ha provocado una estrategia defensiva y que no se aprovechan los recursos de estos nuevos soportes, cada vez más importantes para la audiencia.

14 Texto de la ponencia del autor presentada en el IV Congreso Latina de Comunicación Social, Universidad de La Laguna, Tenerife (España), diciembre 2012. Este trabajo es uno de los resultados del proyecto investigación financiado por Bancaja UMH en el año 2012 con el título: "Los medios de comunicación ante la encrucijada digital: estrategias de producto y de distribución en plataformas móviles". 
Palabras clave: Distribución digital, economía de los medios

\subsection{Introducción}

La industria de la comunicación entra en una nueva encrucijada sin haber salido todavía de la anterior. Si Internet supuso la ruptura del modelo de negocio imperante, el auge de los móviles smartphone ${ }^{15}$ y las tabletas abre nuevos retos estratégicos. Los estudios más fiables del sector estadounidense sugieren que estos dispositivos tienen una incidencia positiva en el consumo de noticias y en el aumento de la lectura en general.

El tiempo y el dinero invertido por los usuarios en móviles y tabletas despejan algunas incógnitas para los editores de prensa, con sus economías en horas bajas (Carvajal, 2011). Al principio, el acceso a las noticias a través de los móviles se producía en los intersticios de las actividades cotidianas (Dimmick et.al., 2010). Gracias a los avances en banda ancha y a las mejoras técnicas, estos dispositivos han cobrado fuerza en otros ámbitos, como el trabajo y el hogar (Westlund et.al, 2011). El aumento de la cobertura y velocidad del UMTS, junto con el descenso de los precios y las estrategias de marketing, han provocado la alta penetración de estos aparatos. En España, 19,3 millones de líneas móviles accedieron a Internet a través de las redes en 2011. De esas conexiones de banda ancha móvil, la mayor parte se realizaron con móviles $(82,5 \%)$ y el resto mediante dispositivos exclusivos de datos -tipo tabletas ${ }^{16}$.

La venta de tabletas y de eReaders crece de forma notable según los analistas (Alonso et al., 2012). En Estados Unidos estos nuevos dispositivos empiezan a quitar tiempo de atención del ordenador y de la televisión (Pew Research Center, 2012). La Asociación para la Investigación de Medios de Comunicación (AIMC) presentó a finales de 2011 "La prensa: digital vs papel", el primero de una serie de informes enfocados en el consumo de los soportes tradicionales frente a internet. El estudio señala que el instrumento prioritario para leer prensa digital es el ordenador portátil $(66,9 \%)$, seguido del móvil $(16,6 \%)$ y la tableta $(4,5 \%)$. En una encuesta similar, la Asociación de Editores de Diarios Españoles (AEDE) descubrió que las actividades preferidas de los usuarios de tabletas eran navegar por internet $(94,1 \%)$, leer prensa online $(86,4 \%)$, acceder al email $(82,1 \%)$ y conectarse a las redes sociales $(75,8 \%)$.

La era de convergencia convierte a los usuarios en consumidores de noticias multiplataforma (Fidler, 1997; Jenkins: 2008). La competencia por los mismos nichos de mercado genera una reconfiguración de la oferta de contenidos (Dimmick, 2010). Los medios reaccionan a las nuevas demandas y se adaptan para estar presentes en todas las ventanas de la convergencia tecnológica (Lawson Borders, 2008). Además, ese proceso coincide con la era de la web social. Los nuevos dispositivos multiplican las posibilidades

15 A partir de ahora, se les nombrará indistintamente, pero siempre se considerarán móviles inteligentes, es decir, con acceso a datos, Internet, mediante $3 \mathrm{G}$ o Wifi.

16 Informe sectorial de Comunicaciones Móviles, CMT, 2011. 
de compartir imágenes, vídeos e información, factores que incrementan o disminuyen el consumo de noticias ${ }^{17}$. Los hábitos de trabajo y la organización de las redacciones también se han visto influidos por la introducción de estos aparatos (Singer, 2004).

Los principales editores internacionales han desarrollado diversas estrategias para rentabilizar sus marcas y sacarle partido a su caudal periodístico en móviles y tabletas. En enero de 2011, News Corporation lanzó el primer diario exclusivo para iPad distribuido a través del quiosco de Apple. En un año consiguió 100.000 suscriptores, lejos de los beneficios esperados, pero positivo en un contexto de innovación y experimentación (Sonderman, 2012). Pocos meses después, Financial Times retiró su aplicación nativa de Apple y lanzó una aplicación web escrita en HTML5 que ganó popularidad y el reconocimiento del sector en pocos meses. El editor del financiero británico aplicó además un modelo de pago, el metered model (Casero Ripollés, 2010), para desarrollar una estrategia de venta coherente en todas las plataformas. Además, con la salida de iTunes se ahorró el 30\% de las ventas que exige Apple a los que circulan por su sistema. The New York Times, en su línea más innovadora, ha experimentado también con los canales digitales. Están presentes incluso en el canal de podcasting de iTunes, donde los columnistas más prestigiosos del diario neoyorquino ofrecen su contenido a los usuarios. Estos editores se adaptan al formato de las tabletas y de los smartphones porque saben que los usuarios fieles a sus valores querrán acceder desde cualquier dispositivo. En ese contexto los editores españoles afrontan el reto de diseñar una estrategia acertada, porque las experiencias no son suficientes y aun no han dado frutos claros. Para eso es necesario conocer mejor los canales de los nuevos dispositivos y aprovechar sus posibilidades.

\subsection{Objetivos, revisión bibliográfica y metodología}

El objetivo inicial del estudio es conocer en profundidad la distribución del contenido periodístico en móviles y tabletas. Eso implica indagar en los aparatos para saber cómo se accede al producto informativo (qué canales emplean), si se adaptan a los requisitos del soporte (cómo son) y a los hábitos de consumo de los usuarios (cómo se comercializan). Se debe calibrar si la oferta de los editores en las tabletas y móviles es convergente con la web social y si sigue el estándar de diseño responsable y usabilidad de los consorcios mundiales de Internet ${ }^{18}$. El objetivo primario es por tanto descriptivo y

17 Ha jugado un papel clave en esta tendencia el fenómeno Apple y la introducción de los sucesivos iPod, iPhone y Ipad. Apple no construyó el primer smartphone, pero la combinación de la pantalla táctil, el desarrollo de los elementos periféricos y la posibilidad de albergar aplicaciones de terceros determinaron su rápido éxito. Los principales competidores de Apple, Samsung y BlackBerry, han imitado y seguido las estrategias de la compañía de la manzana en el diseño industrial.

$18 \mathrm{Ha}$ jugado un papel clave en esta tendencia el fenómeno Apple y la introducción de los sucesivos iPod, iPhone y Ipad. Apple no construyó el primer smartphone, pero la combinación de la pantalla táctil, el desarrollo de los elementos periféricos y la posibilidad de albergar aplicaciones de terceros determinaron su rápido éxito. Los principales competidores de Apple, Samsung y BlackBerry, han 
entronca con otros análisis similares sobre la oferta informativa en la web (Canavilhas, 2009).

Los medios de comunicación cuentan con una amplia variedad de canales para ofrecer su contenido periodístico en móviles y tabletas. Como en Internet, la oferta ha evolucionado en tres etapas (Aguado y Martínez, 2008; Canavilhas, 2010): a) adaptación, caracterizada por las limitaciones del soporte, los medios ofrecían alertas, SMS; b) autonomía, donde los medios configuran versiones propias (tecnología WAP); c) emancipación, con la consolidación de la red 3G, donde la oferta mediática se ha enriquecido y multiplicado en diversas versiones y aplicaciones. Canavilhas (2009) describe cómo es la oferta informativa de diversos medios en móviles, para ello analiza 49 aplicaciones nativas descargadas de la tienda Apple. En un estudio similar, pero de menor alcance, Sanjuan, Nozal y González (2012) comparan las versiones para iPad de El País y Reforma y señalan que estos medios no aprovechan los contenidos multimedia.

Nel y Westlund (2011) también han trazado la evolución de la distribución de noticias en móviles con un estudio longitudinal de 66 periódicos británicos a lo largo de cuatro años (2007-2011). Centran su análisis en cuatro áreas interconectadas: canales, conversación, contenido y comercialización. Su investigación confirma la pérdida de protagonismo de las alertas de SMS/MMS y el auge de las aplicaciones nativas entre los editores británicos.

Esta comunicación forma parte de un proyecto que pretende analizar la distribución digital del contenido de los medios de comunicación. Se enmarca dentro del ámbito de la economía de los medios y pretende servir de trabajo de campo para futuros estudios centrados en la búsqueda de un modelo sostenible para el periodismo. En este caso, el objeto es el sector de prensa, en concreto los seis diarios de información general con mayor difusión (OJD, promedio junio 2011 a julio 2002): El País, El Mundo, ABC, La Vanguardia, El Periódico y La Razón ${ }^{19}$. La muestra es representativa, aunque limitada para realizar análisis intramedios. Por ejemplo, sería relevante comparar la oferta de los editores de prensa con origen en papel con los editores nativos digitales (pure players), como Lainformacion.com o eldiario.es. Los medios elegidos son adecuados porque todos cuentan con versiones digitales de escritorio en la web y disponen de aplicaciones nativas para móviles y tabletas, aparte de vender sus diarios en quioscos digitales. Aparte del contenido, se debía optar por el soporte: se seleccionó los más representativos de cada categoría: el iPhone para los móviles y el Ipad para las tabletas. Otros autores han tomado decisiones parecidas en estudios de similares objetivos (Canavilhas, 2009).

Primero se realizó una exploración digital mediante el rastreo de las webs de los principales editores de prensa españoles a través de los navegadores de las tabletas y de los móviles en octubre de 2012. Después se realizó un proceso de búsqueda y descarga de las aplicaciones nativas de sus diarios en los dos dispositivos. En ese sentido, debe considerarse que las aplicaciones están sometidas a constantes revisiones de programación por parte de los desarrolladores para adecuarlas a las nuevas versiones de

imitado y seguido las estrategias de la compañía de la manzana en el diseño industrial.

19 Difusión (ejemplares): El País 345.243; El Mundo, 233.101; ABC, 190.749; La Vanguardia, 181.900; y

El Periódico, 110.200; y La Razón 97.943. 
los sistemas operativos.

En tercer lugar, se comprobó si los medios contaban con versión móvil o aplicación web en formato HTML5. Por último, se descargaron las aplicaciones de terceros que los medios usan para distribuir su oferta en tabletas y móviles. Una vez determinadas las unidades de análisis, se creó una hoja de cálculo con 21 tablas ( 3 generales y 3 para cada medio) que recoge los principales descriptores para evaluar los canales de distribución. Por último, se realizó un análisis valorativo de esa oferta periodística en los móviles y tabletas mediante la observación directa y la interactuación con el canal. En total, se han evaluado 8 versiones web, 14 aplicaciones nativas, 3 aplicaciones web y 5 aplicaciones de terceros (redes sociales, Flipboard, Pulse, Reader).

\subsubsection{El análisis de las $4 \mathrm{Cs}$}

Para realizar el análisis cualitativo se emplea el método de las 4Cs de Nel y Westlund (2011) que mide el comportamiento de los editores en cuatro niveles: canales, conversación, contenido y comercialización. Esos cuatro niveles, solapados y convergentes, son los factores esenciales para diseñar una estrategia de distribución en soportes digitales.

\subsubsection{Canal}

El canal determina el punto de acceso dentro del soporte. Gracias a los avances tecnológicos, los smartphones y las tabletas ofrecen múltiples puertas de entrada, que varían en función del dispositivo. El smartphone y la tableta comparten elementos técnicos: son móviles, tienen cámara, GPS, audio, pantalla táctil y acceso a datos, 3G o Wifi. Pero conviene distinguirlos porque su diseño influye en el formato del canal. Tipos de canales para distribuir contenido periodístico:

a) SMS / MMS (no requiere de 3G/Wifi): mensajes cortos o mensajes multimedia mediante vía telefónica; el más rudimentario dentro de las opciones que manejan los editores de prensa.

b) Email: con el acceso a datos a través de 3G o Wifi, los medios pueden ofrecer su contenido periodístico a través de correos electrónicos.

c) Web móvil: acceso a los diarios a través del navegador. Dos alternativas:

a. Versión móvil: el navegador dispone (automáticamente o no) una versión especial adaptada al interfaz, se destacan los titulares y facilita la lectura.

b. Versión clásica: el navegador abre el sitio del diario, igual que en el ordenador de escritorio, peor en usabilidad y diseño responsable.

d) Aplicación nativa: programas accesibles e instalables desde el software del aparato; no requieren del navegador y se descargan desde la tienda de Apple mediante pago o gratuitamente; son canales versátiles porque permiten al programador de la aplicación vincularla con la cámara, el GPS, las alertas, notificaciones y demás recursos del dispositivo.

e) Aplicación web: similar a la aplicación nativa, pero que funciona desde el 
navegador, por tanto es independiente de la tienda de Apple (de su licencia y de su comisión), es más flexible para los editores; se suelen escribir en HTML5, un lenguajes de diseño web multimedia, escalable y rico visualmente.

f) Aplicación de terceros: aplicaciones (nativas o web) propiedad de otros, pero que facilitan el acceso al contenido de los editores. De uso frecuente entre los usuarios por su diseño, comodidad de lectura, integración social y nivel de personalización. Hay de tres tipos:

a. Redes sociales y gestores: Twitter, Facebook, etc.

b. Lectores de RSS, agregadores y curadores: Reader, Pulse, Flipboard.

c. Bibliotecas: Readability, Instapaper o Kindle.

g) Quiosco: este canal es similar al homónimo analógico; funciona como un estante desde el que se puede acceder y comprar una publicación. Apple ofrece su propio quiosco desde 2011. Los medios españoles han desarrollado sus propios puntos de venta, como Orbyt y Kiosko y Más.

h) Podcasting: este canal funciona dentro de iTunes y permite a los editores ofrecer piedas de audio con boletines informativos, entrevistas, programas de opinión, magazines, etc. The Guardia, The New York Times o Financial Times los emplean.

\subsubsection{Conversación}

Este apartado evalúa la versatilidad social de los distintos canales. Se ha tratado de medir la capacidad de generar y recoger la conversación de los usuarios (entre ellos, con el medio y en las redes sociales). Algunos son esencialmente sociales, como las aplicaciones de Facebook o Twitter. Si los editores entran en esa dinámica, les resultará más fácil generar conversación. Además, los agregadores, las bibliotecas y los lectores de rss son espacios privilegiados para compartir, enlazar y crear comunidad, pues reciben un constante flujo social que permite afinar la edición del contenido. Aparte de esos canales, el iPhone y el IPad se han diseñado para que desde cualquier aplicación sea fácil compartir por correo electrónico, por Facebook o por Twitter. El análisis evaluará si los medios aprovechan esas posibilidades:

a) Envío por email

b) Compartir en Facebook

c) Compartir en Twitter

d) Comentar noticias

e) Redes sociales propias

f) Contacto, email y otros mecanismos 


\subsubsection{Contenido}

Un análisis de la estrategia de distribución en dispositivos móviles debe medir si el editor se adapta al canal y satisface al usuario. Se deben valorar los elementos del lenguaje cibernético y el aprovechamiento de los recursos del soporte: la hipertextualidad y la multimedialidad, especialmente. También se considerará si los canales ofrecen libertad en el diseño del menú informativo, personalización, y si recurren a las ventajas tecnológicas del dispositivo, geolocalización e interactividad.

Además, se debe evaluar el nivel de usabilidad y de diseño responsable de cada canal. El diseño funciona como la ligazón de contenido y canal, claves en el medio periodístico. Los expertos de esta disciplina consideran que una estrategia de contenido es exitosa si se adapta a los distintos canales de la mejor forma posible. Así evitarán duplicidades en esfuerzo, estrategia, formación y tecnología.

\subsubsection{Comercialización}

En este último apartado se examinan los niveles de comercialización del contenido periodístico en cada canal. Como se indicó, la estrategia de distribución está ligada a la comercialización, por tanto debe medir las alternativas de monetización. Dentro del apartado de comercialización, se estudiará:

a) publicidad: formatos, patrocinios, etc.

b) venta: gratuidad o pago (precio de suscripción y venta de ejemplares).

Los editores pueden diseñar una estrategia comercial gracias a los sistemas de información de marketing: control de audiencia, usuarios, descargas, visitas, etc. La OJD incorpora ya algunos de estos elementos que deben determinar el éxito publicitario de los principales editores. Apple también recoge esa información, lo cual ofrece pistas oportunas para focalizar el producto y testar su penetración.

\subsection{Resultados}

\subsubsection{Canal}

Salvo El Periódico (Grupo Zeta), todos los editores ofrecen alertas SMS con el contenido de sus diarios. Ni el periódico del grupo Zeta (El Periódico) ni el de Planeta (La Razón) ofrecen resúmenes o alertas MMS. Cinco editores disponen de la posibilidad de enviar boletines de noticias, personalizadas o no, por correo electrónico, salvo La Razón. Los diarios analizados aprovechan el canal del navegador del móvil y de la tableta, pero de distinta forma (Tabla $1^{20}$ ).

El navegador del iPhone, por su tamaño, requiere una versión móvil para una adecuada lectura. Los editores de El País, El Mundo, Abc y La Vanguardia sí la ofrecen, aunque los

20 Las tablas se adjuntan en anexo, al final del capítulo. 
de Prisa y Unidad Editorial no se activan automáticamente. La web clásica de El Mundo en el iPhone permite al lector saltar a la versión móvil de una forma más accesible. Zeta y Planeta no ofrecen tampoco una versión móvil, con lo cual, este canal en el smartphone se desaprovecha porque dificulta al usuario el acceso a la información por el tamaño de la pantalla.

Los editores de Vocento y de Godó son los más hábiles en el uso de este canal, puesto que las versiones móviles de sus diarios (ABC, Imagen 5, y La Vanguardia, Imagen 6) cambian automáticamente para adaptarse al soporte mediante el lenguaje HTML5, eso facilita la accesibilidad y la versatilidad de la aplicación.

Todos los diarios cuentan con una aplicación nativa que puede descargarse desde la tienda de Apple. A diferencia de otras aplicaciones, los editores han optado por ofrecer este canal de forma gratuita. Las aplicaciones nativas se descargan y se instalan en el soporte, no necesitan el navegador, pero sí la conexión de $3 G$ o Wifi. Los programadores renuevan estas aplicaciones cada cierto tiempo para adaptarlas al software de Apple, iOS. Del mismo modo, los seis editores ofrecen el contenido periodístico de sus diarios a través de las redes sociales, aunque desarrollan distintas estrategias en este canal social.

El Mundo, La Vanguardia, La Razón y El Periódico además aprovechan uno de los canales más populares del dispositivo iPad, Flipboard. Esta aplicación ha sido top en descargas durante los dos últimos años, por su diseño, comodidad de uso y, sobre todo, porque incorpora el flujo social (Twitter, Facebook). La presencia en este tipo de aplicaciones de terceros es cada vez más relevante, porque el tiempo que los usuarios pasan en ellas es cada vez mayor, como ocurre con las redes sociales en Internet.

Ninguno de los editores emplea el canal quiosco de Apple (Newstand) para distribuir sus diarios, han desarrollado estrategias de distribución propias mediante dos aplicaciones tipo quiosco, Orbyt (Unidad Editorial) y Kiosko y Más (Vocento, Prisa, resto de editores). Orbyt ofrece la versión impresa de El Mundo, entre otros servicios y revistas mediante diferentes paquetes de suscripción y venta. El Periódico y La Razón se distribuyen en Orbyt y en la competencia, Kiosko y Más. Los dos canales funcionan como una aplicación nativa, descargable desde la tienda Apple, con aspecto de estantería. Prisa (El País) y Vocento (ABC) son los promotores de Kiosko y Más, lanzada en 2011, también una de las aplicaciones más descargadas en el iPad, junto a Orbyt. El formato de los diarios en ambos canales es similar, un tipo de pdf enriquecido que permite distintas velocidades y niveles de lectura con escasa multimedialidad.

El diseño del canal debe variar entre dispositivos, porque los usuarios usan, buscan y requieren distintos factores en el iPhone y en el iPad. Aparte de las aplicaciones nativas en el smartphone, todos los diarios ofrecen además una versión específica para el iPad de similares características, pero adaptadas a los recursos del dispositivo. 


\subsubsection{Conversación}

El navegador de Apple (Safari) ha evolucionado tras la última actualización del software en 2012 (iOS 6.0) y ofrece la posibilidad de enviar enlaces por correo electrónico, compartir en redes sociales (Twitter, Facebook) y exportar a bibliotecas o agregadores. Por tanto, los seis editores disfrutan, sin buscarlo, de esas ventajas para integrarse en la conversación de la web social solamente estando en el navegador de los móviles y las tabletas. Sin embargo, aquellos editores que no cuentan con aplicación usable y responsable en diseño no facilitan la actividad social de los lectores.

Las aplicaciones nativas son, en general, sociales, pero no tan versátiles como las aplicaciones web y versiones móviles de las web. La aplicación nativa de El País (Tabla 2), por ejemplo, permite guardar, enviar por email y compartir en redes sociales (Twitter y Facebook), pero no leer o comentar. Es cierto que Prisa ofrece una aplicación nativa para tal fin, Eskup, su red social particular. El Mundo tampoco brinda esa posibilidad (Tabla 3), ni cuenta con red social propia. En su favor conviene señalar que su versión web sí facilita el registro del usuario para comentar noticias. La aplicación nativa menos social es la de La Razón (Tabla 8), con un interfaz pobre, sin interactividad ni opciones de compartir material periodístico. Algo similar ocurre con El Periódico, cuya aplicación nativa en el iPhone solo permite guardar la noticia y enviarla por correo. Sin embargo, su versión para el iPad es más versátil. La aplicación nativa de La Vanguardia (Tabla 7) es la única en la que se puede comentar las noticias.

El canal quiosco (Orbyt, Kiosko y Más) es permeable a la conversación y a la vinculación con las redes sociales, correo electrónico, etc. Sin embargo, los lectores exclusivos de este formato no pueden comentar las noticias. En ese sentido, la gestión del canal quiosco por parte de los editores del estudio supone un paso atrás en una estrategia de distribución social.

\subsubsection{Contenido}

Los editores gestionan de forma distinta la capacidad de los canales en el iPhone y en el iPad. En ese sentido, El Mundo, La Vanguardia y ABC son los que mejor se adaptan al formato del canal en cada dispositivo. La hipertextualidad y la multimedialidad son recursos esenciales en cualquier soporte basado en Internet. Los canales investigados son por lo general hipertextuales y multimedia, sin embargo, el editor de La Razón no aprovecha esos recursos y su web no activa los vídeos, porque están programados en una tecnología inútil para el software de Apple (Flash). Además, su aplicación nativa tampoco ofrece vídeos ni enlaces, un mínimo en estos soportes. El resto de canales de los editores sí son multimedia e hipertextuales (Tablas 8-13), salvo los ejemplares pdf del quiosco que, aunque contienen recursos multimedia, no son hipertextuales.

En cuanto a usabilidad y diseño responsable, La Vanguardia y ABC son los más preparados, porque se adaptan al soporte. No todas las aplicaciones nativas ofrecen la posibilidad de suscribirse a notificaciones, lo cual supone un desaprovechamiento de los recursos tecnológicos. Las aplicaciones web de El Mundo, La Vanguardia y ABC se 
geolocalizan automáticamente, lo que genera un mejor diseño del producto y una más eficaz gestión publicitaria.

Las aplicaciones web ofrecidas por La Vanguardia y ABC, escritas en HTML5, tienen algunas prestaciones que no ofrecen las nativas: no requieren aprobación o licencia del dueño del canal (Apple), son menos costosas, funcionan con el servidor web y se actualizan automáticamente. En cambio, las aplicaciones nativas están abiertas a audiencias más grandes porque son más simples de instalar. Permiten al usuario activar notificaciones, aprovechar los recursos del soporte (cámara, agenda, GPS), y además se cargan más rápidamente y con mejor resolución; también funcionan offline.

Estos canales se ofrecen tanto en iPhone como en iPad. La aplicación nativa no tiene un diseño escalable (automáticamente ajustable al interfaz del dispositivo) y si el editor no la programa, este canal es inútil en otro soporte. Así, una estrategia de distribución para móvil no es necesariamente la más adecuada para la tableta. En la tableta, por ejemplo, es posible la lectura horizontal o vertical. El empleo del click, de los menús y del scroll también difiere. De igual modo, tanto en iPad como en iPhone no es recomendable el uso del lenguaje Flash, pues no se activa por ser incompatible con el software de Apple. La aplicación nativa de El País en el iPad, similar en diseño a la del iPhone, integra también dos emisoras de radio de su compañía matriz, la Ser y los 40 Principales.

\subsubsection{Comercialización}

La comercialización es una parte clave de la estrategia de distribución. De todos los recursos disponibles en el mercado de prensa, los seis diarios analizados limitan sus opciones básicamente a réplicas de sus estrategias en Internet y en el ámbito impreso. Las versiones clásicas de sus webs en los navegadores del iPhone y del iPad incluyen anuncios en formatos similares a la matriz de internet. Las aplicaciones web que ofrecen La Vanguardia y ABC cuentan con alternativas de comercialización publicitaria (cortinillas, intersitials, banners momentáneos, etc.) porque están escritas en HTML5. Las aplicaciones nativas de El País y el Mundo también recogen anuncios (cortinas, vídeos automáticos) y patrocinio: la aplicación de El País para el iPad, por ejemplo, aparece patrocinada por una marca junto a la mancheta, un modelo de exclusividad publicitaria interesante para el soporte.

Los canales de los seis diarios son gratuitos, salvo las alertas SMS/MMS y el canal quiosco, donde los editores cobran por ejemplares y ofrecen distintos paquetes de suscripción y promoción. En ese sentido, ninguna de las aplicaciones emplea estrategias de cobro como el metered model del Financial Times o The New York Times. Las aplicaciones nativas y las versiones web de La Vanguardia, ABC y El Mundo son modelos freemium, puesto que el contenido ofrecido no es el mismo que el vendido en el canal quiosco. 


\subsection{Conclusiones}

Los resultados de este trabajo ofrecen un punto de análisis sobre las estrategias de distribución digital de los editores de prensa en entornos convergentes. El método aplicado, análisis de las 4Cs en móviles (canales, conversación, contenidos y comercialización) se constituye como un válido instrumento para realizar una taxonomía de la distribución de noticias en los dispositivos estudiados, iPad y iPhone.

En las estrategias de distribución de los editores en estos nuevos canales prima la postura de wait and see. Los editores con versiones digitales menos hábiles son también los que peores estrategias desarrollan en el canal móvil. El móvil y la tableta son soportes convergentes, no exclusivos, con gran tendencia al crecimiento, como demostraron los datos iniciales. Por eso, los editores que no los aprovechan están perdiendo la oportunidad de ampliar su cuota de mercado.

El estudio también confirma que los dispositivos de Apple y, en general, todos los de su categoría, ofrecen muchos más recursos en los canales de difusión. La incipiente incorporación de los editores a las aplicaciones de terceros que priman el flujo social debe servirles para ampliar los valores de su marca. El uso de Internet en los dispositivos varía, como señalan diversos estudios sociológicos y académicos. Así, los editores que replican su estrategia en todos los soportes desaprovechan las capacidades. Esto se confirma con la nula presencia de las marcas estudiadas en el canal podcasting, por ejemplo, algo que los editores internacionales ya hacen.

Es importante el lanzamiento del quiosco digital de Unidad Editorial, Orbyt, en 2010, y el de un grupo de editores encabezado por Vocento y Prisa, Kiosko y Más, en 2011. Sin embargo, la aparición de estos canales parece más una posición defensiva del sector, que una estrategia adecuada a las innumerables posibilidades del soporte móvil. Así, ninguno de los editores ensaya estrategias de monetización alternativas a la venta tradicional en los nuevos dispositivos.

Del mismo modo, parece evidente que debe superarse la retórica y la narrativa periodística del soporte papel y del navegador para adaptarla al nuevo entorno. En ese sentido, de los seis editores solo dos han sabido emplear el lenguaje HTML5 que es más asequible y permeable a los avances tecnológicos. Algunos editores, véase La Razón, van en dirección contraria a los consorcios mundiales de diseño responsable y usabilidad; no son conscientes de que sus vídeos no se ven en el navegador del móvil y de la tableta o que sus aplicaciones no tienen la posibilidad de compartir material en redes sociales.

Para futuras investigaciones se deja la forma de rentabilizar los nuevos canales que ofrecen estos dispositivos. Los beneficios económicos y la aportación a la marca de estos canales se podrán testar mediante estudios económicos, por un lado, y sociológicos, por otro. Las respuestas a estas preguntas ayudarán a los agentes del sector, sin duda, y a los estudiosos de la economía de los medios. Los planteamientos germinales de este campo sobre el doble mercado de la información y de la atención deben ser adaptados a unas circunstancias en las que la intermediación del medio es cada vez más difusa. 


\subsection{Referencias bibliográficas}

Alonso-Arévalo, Julio, José-Antonio Cordón-García (2012). "El mercado de los dispositivos de lectura: eReaders y Tabletas." Infoconexión: Revista Chilena de Bibliotecología vol., n. 4 (2012). Enlace: http:/ /bit.ly/S4DsK1.

Aguado, Juan Miguel y Martínes, Inmaculada J. (2008): "La comunicacio?n mo?vil en el ecosistema informativo: de las alertas SMS al Mobile 2.0", en Tri?podos, 23, pp. 107-118, 2008.

Antonio Sanjuan, Teresa Nozal, Ana González, (2009), "Prensa para iPad: usabilidad, interactividad y multimedia en El País y Reforma", en Revista Mexicana de Comunicación, 131.

Carvajal, Miguel (2011), "La crisis de la prensa: análisis del pesimismo", en revista FronteraD, diciembre de 2011. Enlace: http://bit.ly/xIClMD

Canavilhas, Joao (2009), "Contenidos informativos para móviles: estudio de aplicaciones para iPhone", en Textual \& Visual Media 2, pp. 61-80, 2009.

Casero-Ripollés, Andreu (2010) "Prensa en internet: nuevos modelos de negocio en el escenario de la convergencia", en El profesional de la información, 2010, noviembrediciembre, v. 19, n. 6, pp. 595-601.

Dimmick, John W., Feaster, John C., y Hoplamazian, Gregiory (2010), "News in the interstices: The niches of mobile media in space and time", en New Media Society, 18, 2010.

La Vanguardia (2012), LaVanguardia.com lanza su versión móvil pionera en España, publicado 27/06/2012 Enlace: http://bit.ly/TWpOZ8

Nel, François \& Westlund, Oscar (2011), "The 4cs' of Mobile News: Channels, conversation, content and commerce", en Journalism Practice, Volume 6, Issue 5-6, 2012, pages 744-753.

Varela, Juan (2012), The New York Times lanza una web app, 02/12/2012. Enlace: http://bit.ly/QWnJQd

Sonderman, Jeff (2012), "The Daily turns 1 with 100k subscribers, but may be years away from profit", en Pointer.org. Enlace: http://bit.ly/UlRs4j

Fidler, Roger (1997), Mediamorphosis: Understanding New Media. Thousand Oaks (CA), Pine Forge Press.

Jenkins, Henry (2008), Convergence Culture: Where Old and New Media Collide, New York University Press.

Killebrew, K.C. (2005) Managing Media Convergence: Pathways to Journalistic Cooperation, Ames, Ia., Blackwell.

Pew Research Center: Internet Cell Use (2012), United States. Enlace: http://bit.ly/S4vrVy 
Pew Research Center: The State of the News Media (2012), United States. Enlace: http://bit.ly/S4vBfI

Singer, Jane, (2004) "Strange Bedfellows? The diffusion of convergence in four news organizations", en Journalism Studies, 5(1), 3-18.

Lawson-Borders, Gracie (2008), Media Organizations And Convergence: Case Studies of Media Convergence Pioneers, Lawrence Erlbaum. NJ.

OECD (2010), News in the Internet Age: New Trends in News Publishing, OECD Publishing. Enlace: http://dx.doi.org/10.1787/9789264088702-en

\subsection{Anexos}

Notas:

* Debido al tamaño de esta comunicación, el autor no incluyó las imágenes que reunió; pueden solicitarse a mcarvajal@umh.es.

** La recogida de datos para el análisis de las distintas variables se realizó durante noviembre de 2012. El País, por ejemplo, cambió su aplicación web en móvil a finales de diciembre. La actual cuenta con un diseño más responsable.

Tabla 1. Canales ofrecidos por los seis diarios en tabletas y smartphones (11/2012)

\begin{tabular}{|l|l|l|l|l|l|l|}
\hline Canal & $\begin{array}{l}\text { EI } \\
\text { País }\end{array}$ & $\begin{array}{l}\text { EI } \\
\text { Mundo }\end{array}$ & Abc & La Vanguardia & El Periódico & $\begin{array}{l}\text { La } \\
\text { Razón }\end{array}$ \\
\hline Alertas SMS & Sí & Sí & Sí & Sí & No & Sí \\
\hline Resumen MMS & Sí & Sí & Sí & Sí & No & No \\
\hline Correo electrónico & Sí & Sí & Sí & Sí & Sí & No \\
\hline Web clásica & Sí & Sí & Sí & Sí & Sí & Sí \\
\hline Versión móvil & Sí & Sí & Sí & Sí & No & No \\
\hline Aplicación nativa & Sí & Sí & Sí & Sí & Sí & Sí \\
\hline Aplicación web & No & No & Sí & Sí & No & No \\
\hline Aplicación Terceros & Sí & Sí & Sí & Sí & Sí & Sí \\
\hline Quiosco Apple & No & No & No & No & No & No \\
\hline Quiosco Propio & Sí & Sí & Sí & Sí & Sí & Sí \\
\hline
\end{tabular}

Fuente: elaboración propia

Tabla 2. Nivel de conversación de los canales de El Páis en iPhone/iPad (11/2012)

\begin{tabular}{|l|l|l|l|l|}
\hline Herramienta & Web Movil & App nativa & App web & Quiosco \\
\hline Envío por email & Sí & Sí & n. d. & Sí \\
\hline Compartir en Facebook & Sí & Sí & n. d. & Sí \\
\hline Compartir en Twitter & Sí & Sí & n. d. & Sí \\
\hline Comentar noticias & Sí & No & n. d. & No \\
\hline Redes sociales propias & Sí & Sí & n. d. & No \\
\hline Contacto, email, otros & Sí & No & n. d. & No \\
\hline
\end{tabular}

Fuente: elaboración propia. El País no dispone de aplicación web. 
Tabla 3. Nivel de conversación de los canales de El Mundo en iPhone/iPad

\begin{tabular}{|l|l|l|l|l|}
\hline Herramienta & Web Movil & App nativa* & App web & Quiosco \\
\hline Envío por email & Sí & Sí & n. d. & Sí \\
\hline Compartir en Facebook & Sí & Sí & n. d. & Sí \\
\hline Compartir en Twitter & Sí & Sí & n. d. & Sí \\
\hline Comentar noticias & Sí & No & n. d. & No \\
\hline Redes sociales propias & Sí & No & n. d. & No \\
\hline Contacto, email, otros & Sí & No & n. d. & No \\
\hline
\end{tabular}

Fuente: elaboración propia.

*El Mundo ofrece unas aplicaciones en cada soporte, aparte de Orbyt

Tabla 4. Nivel de conversación de los canales de ABC en iPhone/iPad

\begin{tabular}{|l|l|l|l|l|}
\hline Herramienta & Web Movil & App nativa & App web & Quiosco \\
\hline Envío por email & Sí & Sí & Sí & Sí \\
\hline Compartir en Facebook & Sí & Sí & Sí & Sí \\
\hline Compartir en Twitter & Sí & Sí & Sí & Sí \\
\hline Comentar noticias & Sí & No & Sí & No \\
\hline Redes sociales propias & Sí & No & Sí & No \\
\hline Contacto, email, otros & Sí & No & Sí & No \\
\hline
\end{tabular}

Fuente: elaboración propia.

Tabla 5. Nivel de conversación de los canales de La Vanguardia en iPhone/iPad

\begin{tabular}{|l|l|l|l|l|}
\hline Herramienta & Web Movil & App nativa & App web & Quiosco \\
\hline Envío por email & Sí & Sí & Sí & Sí \\
\hline Compartir en Facebook & Sí & Sí & Sí & Sí \\
\hline Compartir en Twitter & Sí & Sí & Sí & Sí \\
\hline Comentar noticias & Sí & Sí & Sí & No \\
\hline Redes sociales propias & Sí & No & Sí & No \\
\hline Contacto, email, otros & Sí & No & Sí & No \\
\hline
\end{tabular}

Fuente: elaboración propia.

Tabla 6. Nivel de conversación de los canales de El Periódico en iPhone/iPad

\begin{tabular}{|l|l|l|l|l|}
\hline Herramienta & Web Movil & App nativa* & App web & Quiosco \\
\hline Envío por email & Sí & Sí & n. d. & Sí \\
\hline Compartir en Facebook & Sí & No & n. d. & Sí \\
\hline Compartir en Twitter & Sí & No & n. d. & Sí \\
\hline Comentar noticias & Sí & No & n. d. & No \\
\hline Redes sociales propias & Sí & No & n. d. & No \\
\hline Contacto, email, otros & Sí & No & n. d. & No \\
\hline
\end{tabular}

Fuente: elaboración propia.

* La aplicación nativa del iPhone no es social, solo cuenta con correo electrónico; en camio, la del iPad sí.

Tabla 7. Nivel de conversación de los canales de La Razón en iPhone/iPad

\begin{tabular}{|l|l|l|l|l|}
\hline Herramienta & Web Movil & App nativa & App web & Quiosco \\
\hline Envío por email & Sí & No & n. d. & Sí \\
\hline Compartir en Facebook & Sí & No & n. d. & Sí \\
\hline Compartir en Twitter & Sí & No & n. d. & Sí \\
\hline Comentar noticias & Sí & No & n. d. & No \\
\hline Redes sociales propias & Sí & No & n. d. & No \\
\hline Contacto, email, otros & Sí & No & n. d. & No \\
\hline
\end{tabular}


Fuente: elaboración propia.

Tabla 8. Recursos del contenido de los canales de El País en iPhone/iPad

\begin{tabular}{|l|l|l|l|l|}
\hline Recursos & Web clásica & $\begin{array}{l}\text { Web } \\
\text { Movil }\end{array}$ & App nativa & Quiosco \\
\hline Hipertextualidad & Sí & Sí & Sí & No \\
\hline Multimedialidad & Sí & Sí & Sí & Sí \\
\hline Accesibilidad & Sí & Sí & Sí & Sí \\
\hline Diseño responsable & No & No & Sí & Sí \\
\hline Notificaciones & No & No & Sí & No \\
\hline Personificación & No & No & No & No \\
\hline Customización & No & No & Sí & No \\
\hline Interactividad & Sí & Sí & Sí & Sí \\
\hline Geolocalización & Sí & Sí & Sí & Sí \\
\hline
\end{tabular}

Fuente: elaboración propia.

Tabla 9. Recursos del contenido de los canales de El Mundo en iPhone/iPad

\begin{tabular}{|l|l|l|l|l|}
\hline Recursos & Web clásica & $\begin{array}{l}\text { Web } \\
\text { móvil }\end{array}$ & App nativa & Quiosco \\
\hline Hipertextualidad & Sí & Sí & Sí & No \\
\hline Multimedialidad & Sí & Sí & Sí & Sí \\
\hline Accesibilidad & Sí & Sí & Sí & Sí \\
\hline Diseño responsable & No & Sí & Sí & Sí \\
\hline Notificaciones & No & No & Sí & No \\
\hline Personificación & No & No & No & No \\
\hline Customización & No & No & Sí & No \\
\hline Interactividad & Sí & Sí & Sí & Sí \\
\hline Geolocalización & Sí & Sí & Sí & No \\
\hline
\end{tabular}

Fuente: elaboración propia.

Tabla 10. Recursos del contenido de los canales de ABC en iPhone/iPad

\begin{tabular}{|l|l|l|l|l|}
\hline Recursos & Web clásica & Web app & App nativa & Quiosco \\
\hline Hipertextualidad & Sí & Sí & Sí & No \\
\hline Multimedialidad & Sí & Sí & Sí & Sí \\
\hline Accesibilidad & Sí & Sí & Sí & Sí \\
\hline Diseño responsable & Sí & Sí & Sí & Sí \\
\hline Notificaciones & No & Sí & Sí & No \\
\hline Personificación & Sí & No & Sí & No \\
\hline Customización & Sí & Sí & Sí & No \\
\hline Interactividad & Sí & Sí & Sí & Sí \\
\hline Geolocalización & No & Sí & Sí & No \\
\hline
\end{tabular}

Fuente: elaboración propia.

Tabla 11. Recursos del contenido de los canales de La Vanguardia en iPhone/iPad

\begin{tabular}{|l|l|l|l|l|}
\hline Recursos & Web clásica & Web app & App nativa & Quiosco \\
\hline Hipertextualidad & Sí & Sí & Sí & No \\
\hline Multimedialidad & Sí & Sí & Sí & Sí \\
\hline Accesibilidad & Sí & Sí & Sí & Sí \\
\hline Diseño responsable & Sí & Sí & Sí & Sí \\
\hline Notificaciones & No & Sí & Sí & No \\
\hline Personificación & Sí & No & Sí & No \\
\hline Customización & Sí & Sí & Sí & No \\
\hline Interactividad & Sí & Sí & Sí & Sí \\
\hline Geolocalización & Sí & Sí & Sí & No \\
\hline
\end{tabular}


Fuente: elaboración propia.

Tabla 12. Recursos del contenido de los canales de El Periódico en iPhone/iPad

\begin{tabular}{|l|l|l|l|}
\hline Recursos & Web clásica & $\begin{array}{l}\text { App } \\
\text { nativa }\end{array}$ & Quiosco propio \\
\hline Hipertextualidad & Sí & Sí & Sí \\
\hline Multimedialidad & Sí & Sí & Sí \\
\hline Accesibilidad & Sí & Sí & Sí \\
\hline Diseño responsable & No & Sí & Sí \\
\hline Notificaciones & No & Sí & No \\
\hline Personificación & Sí & No & No \\
\hline Customización & Sí & Sí & No \\
\hline Interactividad & Sí & Sí & Sí \\
\hline Geolocalización & Sí & Sí & No \\
\hline
\end{tabular}

Fuente: elaboración propia.

Tabla 13. Recursos del contenido de los canales de La Razón en iPhone/iPad

\begin{tabular}{|l|l|l|l|}
\hline Recursos & Clásica & $\begin{array}{c}\text { App } \\
\text { nativa }\end{array}$ & Quiosco \\
\hline Hipertextualidad & Sí & No & Sí \\
\hline Multimedialidad & No & No & Sí \\
\hline Accesibilidad & Sí & Sí & Sí \\
\hline Diseño responsable & No & No & Sí \\
\hline Notificaciones & No & No & No \\
\hline Personificación & No & No & No \\
\hline Customización & No & Sí & No \\
\hline Interactividad & Sí & Sí & Sí \\
\hline Geolocalización & No & No & No \\
\hline
\end{tabular}

Fuente: elaboración propia.

Tabla 14. Opciones de comercialización de los canales de El País en iPhone/iPad

\begin{tabular}{|l|l|l|l|l|}
\hline Comercialización & Clásica & Web Movil & App nativa & Quiosco propio \\
\hline Publicidad & Sí & Sí & Sí & No \\
\hline Patrocinio & Sí & Sí & Sí & Sí \\
\hline Venta & No & No & No & Sí \\
\hline Directa & No & No & No & Sí \\
\hline Suscripción & No & No & No & Sí \\
\hline Freemium & No & No & No & No \\
\hline Metered (contador) & No & No & No & No \\
\hline
\end{tabular}

Fuente: elaboración propia.

Tabla 15. Opciones de comercialización de los canales de El Mundo en iPhone/iPad

\begin{tabular}{|l|l|l|l|l|}
\hline Comercialización & Clásica & Web Movil & App nativa & Quiosco propio \\
\hline Publicidad & Sí & Sí & Sí & No \\
\hline Patrocinio & Sí & Sí & Sí & Sí \\
\hline Venta & No & No & No & Sí \\
\hline Directa & No & No & No & Sí \\
\hline Suscripción & No & No & No & Sí \\
\hline Freemium & No & No & No & No \\
\hline Metered (contador) & No & No & No & No \\
\hline
\end{tabular}

Fuente: elaboración propia. 
Tabla 16. Opciones de comercialización de los canales de ABC en iPhone/iPad

\begin{tabular}{|l|l|l|l|l|}
\hline Comercialización & Clásica & Web Movil & App nativa & Quiosco propio \\
\hline Publicidad & Sí & Sí & Sí & No \\
\hline Patrocinio & Sí & Sí & Sí & Sí \\
\hline Venta & No & No & No & Sí \\
\hline Directa & No & No & No & Sí \\
\hline Suscripción & No & No & No & Sí \\
\hline Freemium & No & No & No & No \\
\hline Metered (contador) & No & No & No & No \\
\hline
\end{tabular}

Fuente: elaboración propia.

Tabla 17. Opciones de comercialización de los canales de La Vanguardia en iPhone/iPad

\begin{tabular}{|l|l|l|l|l|}
\hline Comercialización & Clásica & Web Movil & App nativa & Quiosco propio \\
\hline Publicidad & Sí & Sí & Sí & No \\
\hline Patrocinio & Sí & Sí & Sí & Sí \\
\hline Venta & No & No & No & Sí \\
\hline Directa & No & No & No & Sí \\
\hline Suscripción & No & No & No & Sí \\
\hline Freemium & No & No & No & No \\
\hline Metered (contador) & No & No & No & No \\
\hline
\end{tabular}

Fuente: elaboración propia.

Tabla 18. Opciones de comercialización de los canales de El Periódico en iPhone/iPad

\begin{tabular}{|l|l|l|l|l|}
\hline Comercialización & Clásica & Web Movil & App nativa & Quiosco propio \\
\hline Publicidad & Sí & Sí & Sí & No \\
\hline Patrocinio & Sí & Sí & Sí & Sí \\
\hline Venta & No & No & No & Sí \\
\hline Directa & No & No & No & Sí \\
\hline Suscripción & No & No & No & Sí \\
\hline Freemium & No & No & No & No \\
\hline Metered (contador) & No & No & No & No \\
\hline
\end{tabular}

Fuente: elaboración propia.

Tabla 19. Opciones de comercialización de los canales de La Razón en iPhone/iPad

\begin{tabular}{|l|l|l|l|l|}
\hline Comercialización & Clásica & Web Movil & App nativa & Quiosco propio \\
\hline Publicidad & Sí & Sí & Noí & No \\
\hline Patrocinio & Sí & Sí & Sí & Sí \\
\hline Venta & No & No & No & Sí \\
\hline Directa & No & No & No & Sí \\
\hline Suscripción & No & No & No & Sí \\
\hline Freemium & No & No & No & No \\
\hline Metered (contador) & No & No & No & No \\
\hline
\end{tabular}

Fuente: elaboración propia. 


\title{
] \\ Desarrollo del Periodismo en Línea y Móvil \\ en los diarios mexicanos
}

\author{
Claudia Lerma Noriega \\ Tania Lucía Cobos Cobos
}

Instituto Tecnológico de Monterrey, México

\section{Resumen}

La crisis del periodismo agravada por la dificultades económicas en algunos países (que desemboca en una carencia de anunciantes y compra del periódico impreso), el incremento de usuarios de Internet que acceden a las publicaciones electrónicas, y algunos otros factores; han empujado a que los diarios tradicionales incrementen su participación en la red a través de todos sus canales.

En 2009 México contaba con 314 periódicos con presencia en Internet, cifra que no ha aumentado de manera significativa si se toma en cuenta la aparición de publicaciones hechas exclusivamente para este formato y la desaparición de diarios y revistas.

Asimismo, la adopción por parte de los diarios de mayor presencia en Internet, de las nuevas plataformas móviles (presentes en teléfonos inteligentes, tabletas y e-readers) también se ha manifestado como una pieza importante que permite atraer más lectores y de paso aprovechar las nuevas opciones de interactividad y de aplicaciones que estos dispositivos ofrecen.

Esta investigación recoge los resultados de dos diferentes observaciones al periodismo mexicano: 1. Visualización de la implementación del periodismo digital en los diarios mexicanos -en 2009 y 2012-; y 2. Adopción de las plataformas móviles de los diarios mexicanos, todo ello con el fin de visualizar el crecimiento que han presentado los diarios mexicanos en Internet, en algunos casos no solo para complementar las ediciones impresas, sino también como una opción para desarrollar el periodismo exclusivamente en línea.

Los resultados nos permiten detectar que el periodismo en México tiene un camino bastante prometedor si se continúa adoptando la tecnología de vanguardia y si se ofrecen valores agregados en las versiones digitales; pues el crecimiento de la población que tiene acceso a la red en el país va aumentando considerablemente cada año. 
Palabras clave: Periodismo Móvil, teléfonos inteligentes, plataformas móviles, sistemas operativos inteligentes, plataformas móviles, contenidos periodísticos móviles.

\subsection{Introducción}

Conforme se da una evolución tecnológica se amplían las opciones para que el periódico impreso tenga presencia en la red. En este cambio se desarrollaron los sitios web y se añade la tecnología móvil con sus variados dispositivos (de acuerdo a cada generación) a las alternativas para tener presencia por diversos canales.

En esta segunda década del siglo XXI la movilidad abarca una gran variedad de dispositivos, por lo que el término móvil engloba a todos aquellos inalámbricos y portables como, entre otros, los teléfonos inteligentes, las tabletas y los dispositivos electrónicos de lectura o e-readers.

\subsection{Plataformas digitales y desarrollo del Periodismo Móvil}

En su afán de seguir conservando a su público, de mantenerse a la vanguardia en el uso de avances tecnológicos y de consolidarse como un medio versátil, grandes consorcios de medios periodísticos y empresas pequeñas han adoptado desde hace algunos años una adecuación del medio tradicional a la red, y en algunos casos, han decidido brindar al medio digital la exclusividad de la transmisión de noticias.

Esta opción de acceso vía Internet permite además hacer uso de herramientas de interacción y de colaboración que da una mayor trascendencia entre la amplia oferta de información que circula en la red; en algunos casos, además consolida el denominado periodismo colaborativo. Casi todos los medios conocidos en formato impreso cuentan ya con un posicionamiento entre su público que accede al formato digital, sin embargo han ido adoptando algunos de los valores agregados que el Internet ofrece sobre cualquier otro medio de difusión. Una de estas opciones es la adaptación de la información a la plataforma móvil.

El periodismo móvil puede entenderse desde el punto de vista de la generación de contenido noticioso usando móviles, y también desde la utilización de los móviles como canal de distribución de la información. En la primera acepción, para referirse al ciberperiodismo móvil, Parra Valcarce (2008) lo señala cuando habla de "el tratamiento de la información periodística que permite el envío y la recepción online de textos, imágenes estáticas (dibujos, fotografías, infografías, etcétera), imágenes dinámicas y sonidos de manera integrada, así como la participación de los ciudadanos, convertidos en generadores y evaluadores de contenidos, todo ello utilizando las posibilidades tecnológicas de la tercera generación de la telefonía móvil’. La herramienta por 
excelencia para su desarrollo es el teléfono inteligente.

En su segunda acepción, y en el caso de la prensa, la emergencia y diversificación de los móviles en teléfonos inteligentes, tabletas, e-readers y otros dispositivos, en palabras de la Asociación Mundial de Periódicos (WAN, por sus siglas en inglés), resultan muy prometedores para el futuro de la distribución de noticias. Este aspecto cobra importancia como una forma de hacer frente a la crisis que vive la prensa suscitada -en parte por la gratuidad de la versión digital del mismo (y los desaciertos a la hora de consolidar un modelo de suscripción paga o paywall), la consecución de información noticiosa gratuita en Internet, la disminución de la pauta publicitaria en la edición impresa y la caída de la venta de ejemplares. Ante esta perspectiva, las plataformas móviles son una opción que puede añadirse a otras medidas para solventar los momentos difíciles de la redacción y la administración periodística.

Como ejemplo se puede citar al diario estadounidense USA Today, que en agosto de 2010 anunció una restructuración general que buscaba quitarle énfasis a la versión impresa y concentrarse en contenidos digitales para dispositivos móviles. Esto se tradujo en el despido de 130 empleados y la creación de un Departamento de Desarrollo Digital. "Tenemos que estar donde la gente está", declaró su editor John Hillkirk "si la gente está utilizando el iPad como loca, o el iPhone y otros aparatos móviles, tenemos que estar ahí con el contenido que ellos quieren, cuando quieren".

Dejando de un lado la visión apocalíptica de Estados Unidos, Kittler (1996), afirma que los "nuevos medios de comunicación no hacen obsoletos los viejos medios, sino que les asignan otros lugares en el sistema", en este sentido, como lo explica Canavilhas (2011) se "intenta poner de relieve que a pesar de los cambios tecnológicos, el ecosistema tiene tendencia a requilibrarse, lo que supone un conjunto de readaptaciones de los medios de comunicación existentes a una nueva situación", por lo tanto, las plataformas móviles representan un nuevo cambio tecnológico en la industria de la prensa, ganando espacio como un soporte más para la distribución de información noticia, y reorganizando así el ecosistema existente en este sentido.

Hay que apuntar también que las plataformas móviles o sistemas operativos móviles son mucho más sencillos o simples que los fijos -computador- y se centran en la conectividad inalámbrica, la multimedia móvil y en las diferentes formas de introducción o captura de información, pues como lo menciona Speckmann (2008), un sistema operativo móvil "es un sistema informático que no está vinculado a un determinado lugar, por lo que es posible moverlo o llevarlo, por ejemplo, en un teléfono celular, en un dispositivo portátil o en un sistema especial de cómputo en el automóvil [...]”.

\subsection{Formatos del Periodismo Digital y Móvil}

En México, el periodismo impreso cuando ha decidido hacer presencia en la web lo ha hecho de las dos formas: el volcado, conocido como periodismo 1.0, y que no ofrece 
elementos nada más allá del correo electrónico (no aprovecha las ventajas de la red); y el que adopta ciertas o todas las ventajas que el Internet puede ofrecer (formas interactivas, contenidos creados exclusivamente para la red, actualización con cierta constancia, uso de redes sociales, etcétera). Y es que en México esa explotación del periodismo digital se ha visto limitada porque a pesar de que el uso de la red ha crecido, no lo ha hecho tanto la consulta de noticias.

En el más reciente estudio sobre los hábitos del uso de Internet en México dados a conocer por AMIPCI (mayo 2012) en 2011 40.6\% de los habitantes en México usan Internet, de ellos, el $61 \%$ visita sitios de noticias (sin especificar si son periódicos, revistas, portales, o algún medio en particular). Pero los datos más recientes dados por comScoreMediamatrix en agosto de 2012 señalan que el 97.3\% de los usuarios de Internet en México mayores de 15 años que se conectaron durante el mes de junio recurrieron a la búsqueda de información y noticias. De tal forma que los visitantes únicos a diarios fueron más de 13 millones de personas, y a los de noticias generales más de 15 millones (con conectividad desde el hogar o el trabajo). Estos datos superan por mucho a la media latinoamericana y recogen el interés que tiene el mexicano por enterarse de lo que pasa en su entorno.

Las formas en que los periódicos tratan de tener un acercamiento con su público utilizando la tecnología móvil se centra en: alertas SMS, portales WAP (conocidos también como sitios web móviles), ediciones para dispositivos electrónicos de lectura (ereaders) y aplicaciones o apps Las mismas se detallarán más adelante. En México, las que más predominan son las apps (del inglés applications) y que son programas creados a la medida y por terceros para realizar una tarea específica, que con previa autorización del licenciatario, pueden ejecutarse sobre la misma. En el caso de las aplicaciones de periódicos, estas pueden haber sido desarrolladas por el mismo medio de comunicación, las reconocidas como "oficiales", o por un tercero (como los agregadores RSS). Dado que no hay exclusividad, los diarios pueden tener su aplicación para cada una de las plataformas móviles (iOS, Symbian, Android, BlackBerry OS, entre otras).

La pluralidad de plataformas móviles hace que cada ecosistema sea único, por lo que demanda a la empresa periodística, además de diseñar y sostener un sitio web móvil, el esfuerzo de desarrollar aplicaciones para cada una de estas de acuerdo a las funcionalidades que cada plataforma ofrezca, es decir, se requiere el conocimiento y dominio del SDK (software development kit) de cada una, a lo que se le suma los emergentes estándares de HTML5 y CSS3 que aún generan confusión.

En México el periódico El Universal liberó su versión para e-reader (lector digital Kindle) en octubre de 2009; y también lo hizo O'Globo (Brasil). En la observación hecha en el 2012, se encontró que El Diario de Ciudad Juárez también presenta su contenido vía Kindle además de otros dispositivos electrónicos (aunque en el transcurso del 2009 al 2012 algunos diarios que propusieron esa opción a su público la desaparecieron como el diario Excélsior).

La rápida adopción también fue vista en el caso del diario Vanguardia (Saltillo), pues fue el primer periódico, y medio de comunicación latinoamericano, que desarrolló su versión 
para la plataforma iOS de Apple (iPod Touch, iPhone y iPad) en junio de 2010, y en el caso del dispositivo iPad, un mes antes de que se vendiera oficialmente en México.

Dentro de la variedad de dispositivos móviles además de los tradicionales teléfonos celulares de gama baja, también están los smartphones (teléfonos inteligentes), los ereaders (dispositivos electrónicos de lectura) y las tablets (tabletas o computadores portátiles de mano), que se caracterizan por conectarse de forma inalámbrica a Internet y porque operan con una variedad de plataformas o sistemas operativos móviles: iOS de Apple, Android de Google, Symbian de Nokia, Windows de Microsoft, Blackberry OS de RIM, entre otros. En México es posible conseguir la mayoría de ellos, ya sea a través de tiendas oficiales, distribuidores o revendedores.

El desarrollo de plataformas móviles ha sido diverso y variado, unas están emergiendo, otras predominan, otras han sido rebautizadas, otras han convergido, otras bifurcado, otras están en decadencia y otras han sido abandonadas. Además, su surgimiento y actualización, han sido impulsados por los grandes fabricantes de hardware y software (abierto y cerrado), sin embargo, su adopción, uso, y fidelidad descansa sobre los miles de desarrolladores o developers independientes que crean las distintas aplicaciones o apps que corren sobre las mismas y que distribuyen gratuitamente o con un costo a través de tiendas de aplicaciones en línea o genéricamente app store. Estos desarrolladores pueden ser personas naturales o empresas conformadas para tal fin.

Las primeras plataformas móviles se ubican en 1996 con Palm OS para PDA fabricados por la entonces Palm Computing Inc., y de Microsoft, Windows CE también en 1996 para PDA, Windows Pocket PC en 1998 para su Pocket PC y Windows Mobile en el 2000 para teléfonos inteligentes. Al 2011, de acuerdo con Horace Dediu de Asymco (Finlandia), este era el panorama general del ecosistema móvil (no tuvo en cuenta aquellas cuyo impacto consideró poco significativo, tales como Openmoko, Qtopia, entre otras): 


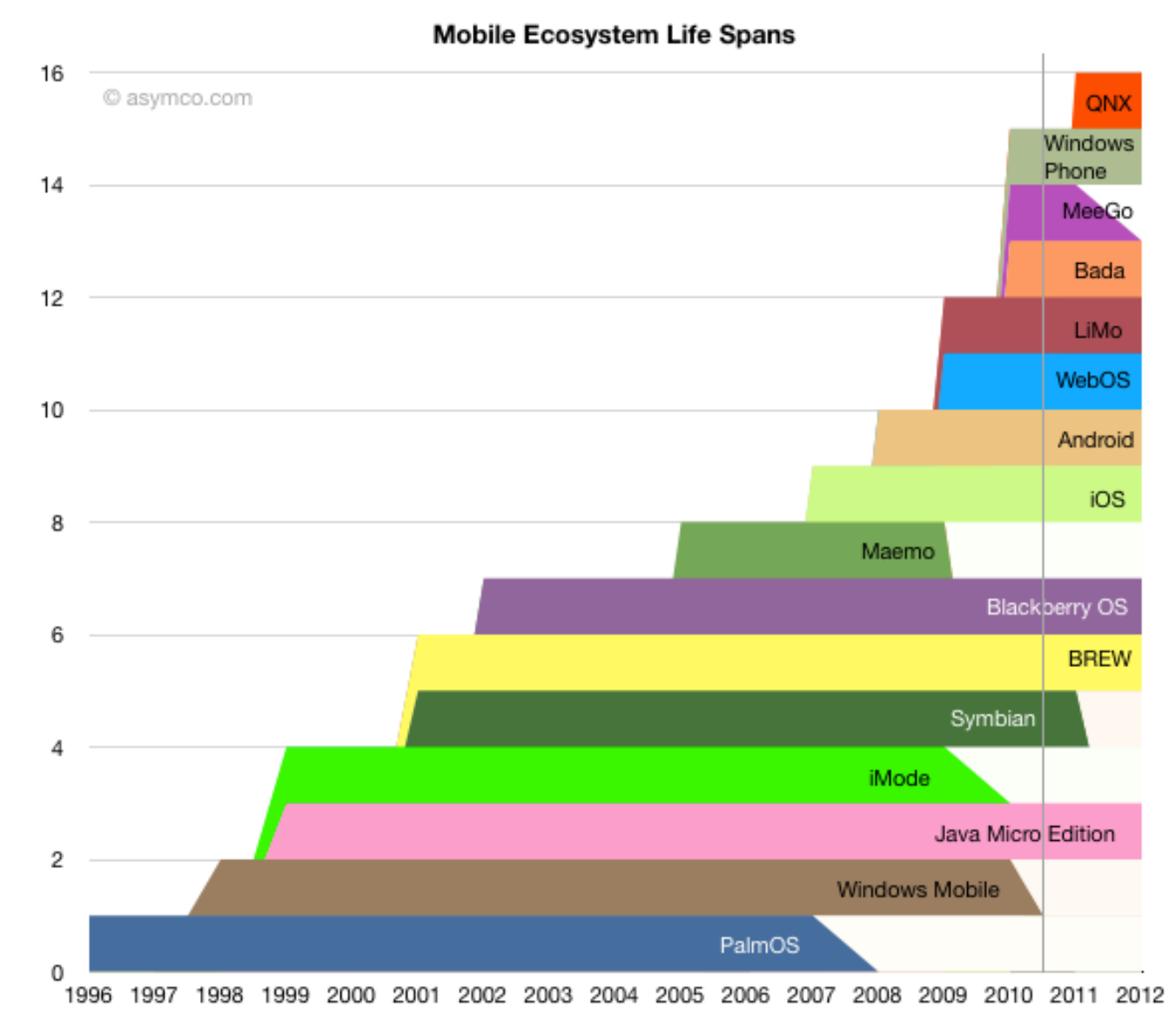

Fuente: http://www.asymco.com/2011/02/19/the-lives-and-deaths-of-mobile-platforms/

Varias de las plataformas o sistemas operativos móviles listados en el gráfico tienen presencia en los diversos dispositivos de tabletas y teléfonos inteligentes que se comercializan en el mercado mexicano como:

- iOS: Desarrollado por Apple, es una plataforma cerrada, basada en Mac OS X.

- BlackBerry OS: Desarollado por Research in Motion RIM (Canadá).

- Android: Basado en Linux, su desarrollo lo inició Android Inc. y lo continuó Google (al comprarla en el 2005) en conjunto con la Open Handest Alliance, en calidad de plataforma abierta.

- Windows Phone: Desarrollado por Microsoft como sistema operativo móvil cerrado basado en Windows CE y liberado comercialmente en el 2010, es el sucesor de Windows Mobile (lanzado en el 2000)

- Bada: Desarrollado por Samsung Electronics (Corea del Sur) desde el 2009 y basado en Linux.

- Symbian: su desarrollo se inició en 1998 bajo el nombre de Symbian OS de la mano de Symbian Ltd. (Reino Unido).

- QNX: Es un sistema operativo cerrado y en tiempo real desarrollado por la 
empresa canadiense QNX Software System desde 1982 y posteriormente adquirida el fabricante canadiense Research in Motion RIM.

Otras plataformas móviles como MeeGo de Intel, Brew de Qualcomm y LiMO de Limo Foundation, no cuentan con dispositivos móviles (o tienen muy pocos) en el mercado mexicano. En el caso de WebOS de Hewlett Packard, a mediados de agosto de 2011 la empresa anunció el desprendimiento de su unidad de hardware (portátiles, teléfonos inteligentes y tabletas) para concentrarse sólo en el software (aunque un mes después se retractó). Esto afectó al OS, que corre en la tableta TouchPad y en los teléfonos inteligentes Palm, sin que quedara claro su futuro.

En el caso de los e-readers, las plataformas y los dispositivos están fusionados y lo que se destaca es el dispositivo. Están concebidos y diseñados para la tarea primaria de la lectura, sea de libros digitales, revistas digitales y periódicos digitales, con algunas funcionalidades adicionales como reproducción de música y navegación web. En el mercado mexicano es posible encontrar variedad de modelos de e-readers de diversos fabricantes, sin embargo, sólo tres de ellos, cuentan con una tienda en línea que permite, entre otros, la suscripción a periódicos digitales. Ellos son el Kindle, de Amazon (con acceso a través de su Kindle Store), los Reader PRS de Sony y su Reader Store y el Nook, de Barnes \& Noble y su Nook Store.

\subsection{Propuestas de contenido para Periodismo Móvil}

Debido al desarrollo del Internet Móvil, omnipresente en todos los dispositivos y plataformas móviles vigentes en 2012 es que marcha el ecosistema de desarrollo de aplicaciones. Entre las apps que se pueden encontrar se hallan las de periódicos o diarios, y pueden distribuirse gratuitamente o con un precio, y actualizarse una o varias veces al día (siendo estas también gratuitas o de pago). En el caso de los e-readers, la funcionalidad permite la suscripción digital; y en el caso de los teléfonos celulares de gama media, el acceso, a través de los navegadores o browser de estos, a la versión móvil (conocidos por la extensión .mobi en su url o porque esta empieza con las palabra "móvil", "mobile" o la letra "m") o la versión clásica de un sitio web.

Actualmente en México, el acceso a Internet a través de dispositivos móviles se realiza de dos formas (sin ser excluyentes); la primera, a través del servicio de telefonía celular o redes celulares con tecnología GSM y UMTS, más conocido como redes $3 \mathrm{G}$ o Internet 3G. En este caso, el usuario contrata un paquete de datos con su operador celular, adicional al servicio básico de voz y mensajería SMS, o puede contratar sólo el paquete de datos. La segunda, es a través de WiFi, un cable que transporte la señal de Internet se conecta a un router WiFi el cual convierte a señal inalámbrica (una señal casera) o se establecen puntos de acceso o hotspots (por ejemplo una red municipal de Internet inalámbrico), en ambos casos, un dispositivo móvil con este estándar incorporado, podrá 
conectarse a Internet usando esta forma.

Feijóo y Maghiros (cit. en Valverde y Aguado 2010), proponen una clasificación básica y orientadora de los contenidos para móviles de acuerdo a las tendencias actuales. De acuerdo a estos, el primer grupo de contenidos son los adaptados y abarcan todos aquellos (entretenimiento, publicidad, noticias) con formatos definidos en otros medios (TV, radio, Internet) que sufren un proceso de adaptación a las características de la plataforma móvil. El segundo grupo de contenidos son los específicos, aquellos que se diseñan específicamente teniendo en cuenta las potencialidades del medio móvil (comunicación, personalización, contextualización, localización, etcétera). En este sentido Valverde y Aguado (2010) señalan que si hace unos años la tendencia era trabajar con contenidos adaptados, actualmente se tiende a crear contenidos específicos teniendo en cuenta las posibilidades que ofrecen las nuevas plataformas y dispositivos móviles.

Agregan que en lo que respecta a la tipología de contenidos periodísticos móviles, resultan evidentes en la oferta actual dos características: homogeneidad y especificidad incipiente. El primero se refiere a que los medios distribuyen sus productos y servicios de manera muy similar, y el segundo, el evidente conservadurismo (aprovechamiento de lo que ya se tiene o se hace), con un tímido asomo evolutivo a una especificidad cada vez mayor. Si bien ellos exponen los anterior basándose en un análisis a medios españoles, lo anterior es posible extrapolarlo, en este caso, a los diarios mexicanos tomados en este estudio, tal como se verá más adelante.

Como se mencionaba párrafos atrás, las formas de distribución de contenidos de periódicos en plataformas móviles son las siguientes:

\subsubsection{Alertas SMS}

El primer servicio que ofreció la prensa para móviles fue el envío de alertas SMS a teléfonos celulares, remontándose los primeros casos al año 2000.

Los usuarios podían suscribirse suministrando su número telefónico a través del sitio web del periódico, al envío de SMS noticiosos a su celular. Estos contenidos podían ser titulares del día, noticias de último minuto, paquete de noticias o algún especial. El periódico establecía con cuál operador estaba activo el servicio, el número de mensajes a recibir y el horario de envío, además si la suscripción se establecía por un período de tiempo o por cantidad de mensajes.

También el servicio se prestaba teniendo como intermediario al operador celular. Este ofrecía el servicio (que podía mencionar o no el periódico de acuerdo a lo estipulado en la alianza) y el usuario las recibía. Usualmente fue un servicio con costo, aunque ocasionalmente se ofrecía gratuitamente. También el servicio abarcó la modalidad de mensajes MMS, por ejemplo, para el envío de imágenes y fotografías noticiosas.

En México aún hay varios periódicos (y operadores celulares como Telcel) que mantienen activo el servicio vía SMS, especialmente enfocados a los celulares de gama baja. Para el proceso de suscripción, el usuario debe enviar una palabra a un determinado código numérico, por ejemplo, “envía NOTI al 84832 desde tu Telcel”. 


\subsubsection{Paso de portales WAP a portales móviles}

Los portales WAP surgieron en la segunda generación de la telefonía celular, entre los años 2002 y 2003. Este protocolo incluido en las nuevas gamas de teléfonos celulares y PDA permitía la navegación, aunque lenta y dificultosa, de sitios WAP, es decir, sitios diseñados exclusivamente para ser navegados a través de estos dispositivos. Usualmente eran una versión con resolución de pantalla reducida, textos cortos e imágenes en baja calidad de la versión web del diario. Sus url se reconocían por su extensión .wml o porque su dominio empezaba con la palabra wap (dominios del tipo wap.nnn.com). El acceso per se al portal wap del periódico no tenía costo, el precio que pagaba el usuario radicaba en la transferencia de datos que hacía en la red celular para poder cargarlo.

Con el paso de los años, el incremento de la velocidad en cada generación de la telefonía celular, las nuevas versiones del protocolo wap, el desarrollo de los navegadores para móviles y el lanzamiento de dispositivos móviles con pantallas más grandes, permitió la evolución de estos portales a los que hoy son conocidos como sitios web móviles.

En el 2005, la ICANN aprobó el dominio .mobi (del inglés mobile) enfocado al registro de sitios diseñados para dispositivos móviles en general, así cómo los estándares que deben cumplir este tipo de sitios. Actualmente éstos se identifican no sólo por su terminación .mobi, sino también porque utilizan la letra m o la palabra móvil /mobile para sus url (Ej: m.ppp.com).

Si bien el contenido principal sigue siendo el texto, ya se despliegan gráficas e imágenes fijas en mayor resolución como el encabezado del sitio, publicidad, fotografías, íconos, entre otras, además variedad en los colores, diseño más estilizado y una estructura de navegación optimizada para pantallas pequeñas.

En lo relacionado al costo, es el usuario quien asume el pago de la transferencia de datos que demande navegar el sitio web móvil (el mismo viene incluido en lo que se conoce como plan de datos, paquete de datos, plan Internet Móvil o Internet $3 \mathrm{G}$ que se haya adquirido), y si bien el acceso al contenido suele ser gratuito, algunos diarios han establecido paywall o sistema de pago, extendiendo el que está presente en su versión web. El usuario que se haya suscrito utiliza por lo tanto su usuario y contraseña para acceder a la versión móvil como a la web.

Cabe recalcar que no todos los diarios cuentan con una versión optimizada para móviles, por lo que si alguien, usando su dispositivo móvil, ingresa al sitio del mismo no se sucede un redireccionamiento a la versión móvil sino que se despliega la versión web es que no se ha adecuado a una versión de este tipo. En este sentido es de destacar que dado el tamaño de las pantallas móviles, la apertura de ésta versión del diario puede dificultar la experiencia de navegación, obligando al usuario a realizar permanentemente zoom in y zoom out para poderlo recorrer y leer.

\subsubsection{Aplicaciones o apps}

Desde la aparición de las primeras plataformas móviles se incentivó el desarrollo de apps. Apple le dio un gran impulso al desarrollo de aplicaciones móviles en los años 
2007 y 2008 cuando lanzó la plataforma móvil iOS para sus dispositivos iPhone y iPod Touch. Con la implementación del programa Apple Developer le permitió reclutar desarrolladores freelance ${ }^{21}$, les brindó el iOS SDK (software development kit) y una serie de herramientas de programación, Xcode, para que crearan aplicaciones de toda índole, incluyendo noticiosas. Las aplicaciones, una vez revisadas y aprobadas por Apple, son distribuidas exclusivamente, de forma gratuita o de micropagos, a través de su App Store.

La estrategia resultó ser exitosa por lo que fue replicada de forma similar por otras plataformas competidoras como Symbian, Android o BlackBerry OS, estructurando cada una su propio programa para desarrolladores freelance, un SDK, tiendas digitales distribución, sistema de micropagos, programa de comisiones por ventas, entre otros aspectos. Las aplicaciones no firman acuerdo de exclusividad por lo que el desarrollador puede diseñar la misma aplicación para correr en tantas plataformas como desee o requiera.

Entre las diversas aplicaciones noticiosas que se pueden encontrar en las variadas plataformas están las de periódicos.

El micropago por descargar la aplicación es variable, e incluso puede ser gratuita. De la misma forma, el acceso a la información que se actualiza al menos una vez al día puede requerir un micropago o también ser gratuita, situación que impera en la mayoría de los diarios que en México utilizan estas plataformas para difundir la información entre sus lectores.

Dado el nuevo ambiente que implica el móvil, con sus características de portabilidad, de pantallas pequeñas, de conexión y de respuesta a programas informáticos; el diseño gráfico y la arquitectura de información de las aplicaciones para periódicos ha requerido ingenio para la optimización del mismo, yendo de la mano con el ofrecimiento de contenido enriquecido (audio, video, texto e imágenes), redes sociales, publicidad y funcionalidades.

\subsubsection{Edición para dispositivos digitales de lectura}

Para competir con el papel, los dispositivos digitales de lectura necesitan una serie de cualidades, entre ellas, portabilidad, simplicidad y legibilidad, y aunque las suscripciones digitales a periódicos (y revistas) están disponibles, poco se sabe sobre su posible potencial como sustituto de las publicaciones impresas, particularmente cuando se encuentran fuera de su mercado geográfico, afirman Hollander et al. (2011).

Aunque hablar tajantemente de sustitución es exagerado, dada las características de los dispositivos electrónicos de lectura o e-readers, varios periódicos han adoptado también este medio como otra forma de distribución global de sus contenidos. Para tal fin han establecido contacto con las compañías propietarias que los ofrecen y que cuentan con

21 Vale la pena anotar que el desarrollador interesado en participar en el programa debe pagar una cuota anual de US\$99 dólares que incluye el software de desarrollo, escaparate en la tienda, entre otros. Apple reconoce el 70\% de ganancias al desarrollador por cada copia de aplicación vendida. 
una tienda de contenidos que le brinda este servicio, tales son Amazon y el Kindle, Sony y los Reader PRS, y Barnes \& Noble y el Nook.

Los e-readers de estos propietarios no son piezas únicas, sino que también cuentan con diferentes modelos donde varía el tamaño de la pantalla, si tienen teclado físico o son touchscreen, tipo de conectividad ( $\mathrm{WiFi}, 3 \mathrm{G}$ ), archivos que soportan, entre otras características.

Se encontraron dos estrategias que permite a la prensa estar disponible para estos dispositivos. Por un lado, Amazon ha creado el Kindle Publishing for Periodicals, donde el periódico interesado debe solicitar una membresía, y una vez aprobada debe ajustarse a las especificaciones técnicas que se le solicitan y demás condiciones con respecto al modelo de negocio y frecuencia de actualización que manejan. Por el otro, en los casos de Sony para sus Reader PRS, y Barnes \& Noble para su dispositivo Nook, ambos establecen acuerdos directos con los propietarios de los periódicos para vender suscripciones digitales en sus dispositivos. Las especificaciones técnicas y el modelo de negocio son establecidos por las compañías y estandarizados a todos los diarios que se distribuyan en estos.

Adicionalmente, empresas internacionales dedicadas a la distribución multicanal de periódicos y revistas, como NewspaperDirect y Pressmart, han establecido acuerdo con estas compañías, Amazon, Sony, y Barnes \& Noble, para poner a disposición de los usuarios de estos dispositivos su catálogo que incluye diarios de diferentes países, entre ellos México. Estos distribuidores han desarrollado aplicaciones para las diferentes plataformas móviles con el mismo objetivo.

Los diarios en e-reders cuentan con características particulares independiente de la compañía con que estén, donde se destaca principalmente el tratar de recrear la experiencia de un periódico impreso, en palabras de Vavrus (2011) "los e-readers se parecen más a la experiencia analógica de lectura". De igual forma, su actualización va de acuerdo a la frecuencia de publicación del impreso (una vez al día, una vez a la semana, etc), y no hay exclusividad, un mismo diario puede estar disponible para los dispositivos de cada compañía.

En lo que se refiere al esquema de suscripción digital el mismo ha sido pago para estos dispositivos desde sus inicios y es igual en las tres compañías. El usuario interesado puede obtener por catorce días una suscripción gratuita a modo de prueba, posteriormente, si quiere continuar, deberá pagar una determinada suma mensual. También es posible que el usuario pueda comprar sólo la edición del día.

Las compañías propietarias de los e-readers tienen o están trabajando en aplicaciones o reading apps que les permitan a sus usuarios disfrutar de las suscripciones digitales que han adquirido sin necesariamente estar atados a sus dispositivos, sino que también puedan abrirlas en otros dispositivos móviles que tengan como tabletas y teléfonos inteligentes (independiente de la plataforma), e incluso computadores portátiles y de escritorio. 


\subsubsection{Aspectos que configuran una aplicación noticiosa para móviles}

En el 2010, la Digital News Test Kitchen de la Universidad de Colorado (Estados Unidos), presentó el informe de investigación In-depth News for Smartphones, en este afirma que así como los teléfonos celulares tienen la capacidad de enviar y recibir noticias al instante en modo texto (SMS), los de última tecnología como los teléfonos inteligentes tienen características como pantallas más grandes, audio, video, imágenes, localización geográfica y otras avanzadas que hacen de estos un gran medio para las noticias. Esta apreciación se extiende además a otros dispositivos móviles como las tabletas y los reproductores multimedia portátiles y reiteran que no debe tratarse con descuido el paso del computador al móvil, tal como se hizo en la década los noventa cuando ocurrió la transición del impreso a la web.

Las empresas periodísticas han empezado a dedicar esfuerzo y creatividad a la creación de contenidos específicos aprovechando las amplias características que presentan los dispositivos móviles, y que son soportadas por las plataformas que corren en los mismos, sin embargo, todavía hay un gran número de proveedores de noticias que no descubierto la manera de sacar el máximo provecho de éstas. Funciones como realidad aumentada, códigos de barras en 2D y transacciones monetarias dentro de la aplicación aun son inexploradas.

Destacan que son los jóvenes los mayores de consumidores de tecnología móvil, misma que a su vez se caracteriza por ser la de más rápida adopción que cualquier otra tecnología, por lo que para las empresas periodísticas, se convierte en una oportunidad de acercarse a las generaciones que se han habituado a consumir información desde la cuarta pantalla. El diseño de la información noticiosa para móviles debe estar orientada al público joven, concluyen.

Como una forma de ayudar a los proveedores de noticias, entre ellos los periódicos, que están intentando adaptarse a esta nuevas tecnología y sacar provecho de ella, el informe identificó quince áreas de oportunidad que deberían contemplarse al momento de diseñar/desarrollar para móviles, de acuerdo con las características del dispositivo y la plataforma destino. Si bien fueron formuladas para teléfonos inteligentes son entendibles también a tabletas. Los elementos a considerar son:

1. Intensificar la interacción entre la aplicación y el usuario: esta se puede incrementar al permitir comentarios sobre la noticia, así como ver y responder los comentarios que han hecho otros usuarios de la misma a través de la versión web y de la móvil. También se puede activar la opción para que dicho comentario sea enviado en forma de archivo de audio, y con un programa de reconocimiento de voz, se transcriba y aparezca en la zona comentarios publicado como texto. Muchas aplicaciones ya se centran en el reconocimiento de voz. Otra estrategia es habilitar la etiquetación geográfica del comentarista, siempre y cuando el usuario autorice con conocimiento de causa la recopilación y publicación de este dato. Otra es dar la opción que al comentario se le pueda adjuntar una fotografía o un video (con geolocalización en ambos casos) si por ejemplo son testigos presenciales de la noticia que están comentando. También se puede ampliar la 
función de encuestas a los usuarios de móviles, es decir, que las encuestas que están presentes en la versión web también puedan visualizarse en la app y en la versión web móvil, e incluso mostrarle al usuario los resultados de ésta de acuerdo a su ubicación geográfica (ciudad).

2. No limitarse al mero volcado de información de un soporte a otro, Periodismo 1.0, sino generar contenido exclusivo para móviles: pues aunque el contenido publicado en otros soportes (impreso y web) funge como base, se deben desarrollar nuevos servicios e innovadoras funciones que mejoren la experiencia móvil y generen un valor diferencial para el usuario, es decir, que sólo pueda hallarse y replicarse en este ambiente. Con la función de geolocalización activada, puede rastrearse la posición geográfica del usuario y priorizar las noticias y otros contenidos que se han generado en y para el lugar donde se encuentra ubicado. Dadas las características de estos dispositivos, es posible que el usuario contribuya con el envío de material que sea de utilidad para complementar la cobertura de una noticia a cargo de un periodista profesional, especialmente en casos de desastres.

3. Pedir y dar cabida a contenido móvil proporcionado por el usuario, no sólo se refiere al desarrollo especializado de paquetes de noticias en profundidad para móviles y otro tipo de presentaciones de noticias para móviles, sino que abarca la recopilación de información del usuario y otros datos que son útiles para extender una historia y añadir material al trabajo inicial desarrollado por un periodista profesional. El móvil es una herramienta ideal para que los ciudadanos compartan lo que saben o han experimentado, ya que pueden hacerlo desde cualquier lugar, incluso desde los escenarios que son noticia en cubrimiento. Los proveedores de noticias, incluyendo por supuesto periódicos, pueden aceptar fotos y breves clips de audio y video e incluso textos de testigos presenciales en casos de noticias de última hora (después de la publicación de la noticia), la aplicación móvil que se genere para tal fin deberá pedir permiso para geolocalizar imágenes y videos, así como otros permisos que deberá otorgar el usuario para la reproducción del contenido que está aportando. Muchos diarios a nivel mundial ya recurren a ello pidiendo fotografías de los lectores, videos o denuncias en tiempo real a través de sus dispositivos móviles.

En el ámbito del periodismo de investigación, una vez publicada la noticia, el paquete noticioso no necesariamente debe finalizar ahí, para determinados temas es posible que usando el móvil, la empresa periodística solicite a sus usuarios, en la medida de sus capacidades, el envío de material geolocalizable para continuar el cubrimiento post-suceso, especialmente de situaciones donde el acceso al periodista profesional puede estar vetado o restringido por las autoridades. Igualmente en este ámbito, y antes de la publicación, cuando sea apropiado y en el proceso de preparación de la noticia, el periodista puede contactar a un público determinado o a un grupo expertos en un tema acerca del proyecto de la misma para que éstos, a través del uso de móviles, puedan hacerle llegar con antelación el material que será utilizado en el paquete de la misma. 
Finalmente se encuentra la implementación de la realidad aumentada. Esta es una funcionalidad de reciente incorporación, consiste en la adición en tiempo real de información virtual a una información física ya existente creando así una realidad mixta. Para tal fin el dispositivo móvil debe contar con una visión por computador y reconocimiento de objetos, así cuando el usuario la utilice, se va mostrando en su dispositivo, información adicional agregada digitalmente sobre lo que está observando físicamente a través del mismo. Esta funcionalidad puede implementarse por ejemplo en lugares que fueron escenarios de la noticia, permitiendo a los usuarios añadir información (texto, video, imágenes, audio) a una ubicación específica, así como visualizar la que otros han añadido.

4. Aprovechar la capacidad de la ubicación geográfica, los dispositivos móviles conectan lo digital con lo tangible, lo que le da una oportunidad al periodismo de regresar a sus raíces basadas en la localización. Para aprovechar la función de geolocalización, se sugiere etiquetar el contenido con los datos de ubicación geográfica (artículos, fotografías, audio, video), esto hace posible la creación de mapas de noticias para los usuarios web y ayuda a los usuarios de móviles en el descubrimiento de información y noticias cercanas basándose en su ubicación física actual. Además se puede habilitar el preguntarle al usuario si desea activar la geolocalización o de geolocalizarlo automáticamente si este la ha habilitado previamente y a continuación proporcionarle contenido que se adapte a donde se encuentra; permitir añadir al usuario su ubicación, si este quiere hacerlo, al momento de dejar comentarios y ubicar en un mapa a los mismos.

Otra opción es enlazar el contenido basado en la ubicación geográfica de otras fuentes pertinentes, no solamente limitarse a vincular información de su propio sitio, en el caso de noticias de última hora se pueden añadir enlaces, previa verificación, a tuits en Twitter y a blogs que incluyan geoubicación de sus datos, con una agupación de feeds provenientes de diversas fuentes y disponibles en el sitio web móvil, se ofrece una capa de contenido en tiempo real como complemento a la cobertura en profundidad. La utilización de la geolocalización no debe hacerse porque sí, deben identificarse las historias y los temas que tienen una fuerte conexión con el lugar, de tal manera que la geolocalización enriquezca la noticia y la conecte con el usuario, si se considera irrelevante o superflua la geoubicación de los datos, entonces evitarla. Por último, debe respetarse la privacidad de los usuarios de móviles, una aplicación móvil o un sitio web móvil debe geolocalizar al mismo con el expreso permiso de este, sea para entregar contenido geográficamente dirigido, obtención de noticias o captación de sus datos.

5. Aprender a aprovechar la realidad aumentada para noticias en móviles, esta tecnología se ofrece como una herramienta para la elaboración de narrativas interactivas que brinden información sobre sucesos pasados y futuros acontecidos en los diferentes espacios del lugar donde se encuentra el usuario ubicado físicamente. Sin embargo, dado que aún no es un tecnología popularizada en los dispositivos móviles ni presente en portátiles o computadores de mesa, no se debe 
descuidar la elaboración de visitas virtuales o a distancia de esos sitios, es decir, una emulación de esa realidad mixta y que pueda recorrerse e informarse de la misma manera sólo sin estar físicamente en el lugar, en otras palabras, ofrecer una experiencia de realidad aumentada desde la distancia. La realidad aumentada sólo debe usarse si realmente contribuye a enriquecer el poder de la narración, si no está contextualizada, ni permite interactividad, ni proporciona un nuevo nivel de comprensión espacial, es preferible descartarla.

Por ser una tecnología en estado experimental, se sugiere hacer uso de servicios de terceros que permiten desarrollar este tipo de funcionalidades gratuitamente como Layar, Acrossair o TagWhat. También se sugiere jugar con la individualidad ofreciendo una experiencia personalizable a cada usuario, es decir, permitir a los usuarios elegir que quieren ver a través de las capas de contenido seleccionable. Finalmente el uso de la realidad aumentada para llegar a una forma más contextualizada del periodismo, ya que esta se presenta como la encarnación digital del contexto.

6. Utilizar textos e imágenes como contenido básico para móviles. Experimentar con nuevas tecnologías como la realidad aumentada no implica descuidar lo básico. El texto es el método preferido para el consumo de noticias en móviles, seguido por las fotografías y luego el audio y el video. El texto es consumido rápidamente, mientras que las imágenes, y especialmente el audio y video, requieren de más tiempo, además que demandan mayor consumo de datos o disponibilidad sin intermitencia de $\mathrm{WiFi}$, por lo tanto su uso debe ser moderado y cuando sea más conveniente o apropiado, y que no sean muy extensos. Debe procurarse un uso innovador de las fotografías, experimentarse con la narración a través de fotos, especialmente cuando son relatos en texto son muy largos que el usuario móvil seguramente no terminará de leer.

7. Ofrecer la opción de noticias en audio. Para los usuarios es habitual reproducir música en sus móviles, por lo que esta característica es aprovechable para generar noticias en clips de audio, como complemento al paquete noticioso o la presentación misma de la noticia leída, ya que se presenta como una opción de consumo noticioso para cuando se realizan actividades como conducir o correr, o cuando la noticia es de texto muy extenso. Por otro lado, permite llegar a los usuarios que padecen deficiencias visuales que les impiden leer. Debe considerarse que la conexión a Internet del usuario, vía $3 \mathrm{G} / 4 \mathrm{G}$ o redes WiFi puede no ser siempre óptima, por lo que si es posible incrustar el audio, por ejemplo en una aplicación, es preferible hacerlo, así como precargas del mismo cuando el usuario esté conectado de manera que lo pueda escuchar de forma offline. En el caso de que el audio corresponda a ser noticia leída, debe facilitarse la opción de que el usuario pueda cambiar a otro audio desde la misma opción donde está escuchando, así como también el flujo continuo, por otro lado, debe tenerse en cuenta la voz que lee, si bien ha avanzado en la tecnología de voces robóticas con los diferentes géneros y acentos, estas aún pueden resultar muy mecánicas y tediosas para quien las escucha, por lo que es preferible un locutor humano 
competente.

8. Mostrar a los usuarios de móviles el tiempo estimado de lectura, así como la duración de los clips de audio y video. Las pequeñas pantallas de los teléfonos inteligentes (así como la de los reproductores multimedia portátiles), a diferencia de las de las tabletas, no son cómodas para lecturas largas, además de que los usuarios no suelen ver videos extensos o escuchar audios extensos en estos dispositivos. Esto plantea una interrogante sobre cómo presentar los contenidos en profundidad en sitios móviles o aplicaciones. Si bien es aún un área de experimentación para los móviles, pueden aplicarse estrategias como informar el número de palabras de texto o un estimado del tiempo de lectura, utilizar una barra que marque en porcentaje el progreso de lectura, así como la tienen los clips de audio y video que marcan el tiempo, esto le permitirá usuario tener un estimado de cuanto le falta para terminar. Publicar el tiempo de duración de los clips de video y audio; y en el caso de paquetes noticiosos, informar en una tabla el tiempo estimado (o número de palabras cuando aplique) que el usuario deberá dedicar a cada componente.

9. El uso de marcadores o bookmarks que "recuerden" en el móvil el lugar en que estuvo el usuario. Los usuarios aprovechan los cortos o medianos bloques de tiempo como esperar en filas o durante el recorrido del autobús o metro para usar sus dispositivos, entre ellos, consultar las noticias. En el caso de una aplicación, para facilitarle al usuario el recorrido puede implementarse una característica de "regresar a lo último leído", de tal manera que cuando el usuario salga y regrese, la aplicación le pregunte si desea volver al último punto donde estuvo en su anterior visita. De igual forma, los clips de audio (incluyendo si son noticias leídas) y los videos deben tener un punto de quiebre, es decir, que se memorice el último segundo que se escuchó/vio de tal forma que se reinicie a partir de allí cuando el usuario vuelva a reproducirlo. En el caso de paquetes noticiosos, la tabla de contenidos puede ir marcando de manera visible los ítems ya visitados. Asimismo, ofrecer un servicio de alertas, sean SMS, mensaje de vOz o una notificación push en el móvil, que el usuario active previamente para recordar el volver al contenido. sticaDe igual forma, agregar a los resúmenes de paquetes noticiosos, una funcionalidad "recordarme leer esto después" que el usuario active y así reciba una notificación posteriormente que le invite volver.

10. Sincronización para el consumo de noticias multi-dispositivo (en la nube). El usuario normalmente cuenta con más de un dispositivo móvil, puede empezar a leer las noticias desde un teléfono inteligente y continuar luego a través de una tableta, por lo tanto es ideal que exista una sincronización en las aplicaciones, es decir, que la última aplicación usada recuerde el último lugar de visita y cuando vuelva a ingresar desde otro dispositivo, este retome desde donde quedó. Es lo llamado portabilidad de contenidos a través de diversos sistemas e interfaces (en la nube), que no sólo abarca móviles sino también PCs de escritorio y portátiles, y que por supuesto requiere que el usuario se registre e inicie sesión. La sincronización también puede hacerse extensiva a los comentarios que se han 
dejado tanto a través de móviles como de computadores de escritorio, que se visualicen en uno y otro.

11. No alejarse de los estándares y normas de interface. Si bien se alienta a innovar y experimentar en la presentación de contenidos para móviles, también debe tenerse en cuenta las funciones que vienen predeterminadas en cada plataforma, como por ejemplo los diferentes movimientos de los dedos o la forma de navegación. El desarrollo de aplicaciones para presentación de noticias debe centrarse en los estándares especificados, ya que el objetivo primario es crear nuevas presentaciones haciendo uso de las herramientas de navegación pre-existentes. Cualquier nueva característica que salga de estas debe explicar y defender su importancia. Las actualizaciones de aplicaciones y de sitios web móviles deben abordarse de la misma manera, los usuarios podrían perderse fácilmente en rediseños radicales de interface, especialmente cuando estos no han sido buscados por ellos (el caso de Facebook). Los usuarios esperan estandarización también en la presentación de los contenidos vía web móvil independiente de la plataforma que usen sus dispositivos, es decir, que si usan BlackBerry, iPhone o un teléfono inteligente con Android, el contenido será igual de accesible que si estuvieran visualizándolo desde el navegador de su computador.

12. Los adolescentes deben ser el público objetivo de noticias en móviles. Los proveedores de noticias deben orientar los diseños y desarrollos hacia ellos pues son un mercado ideal ya que esta es una generación que nació en la era de Internet, ha tenido contacto con la red de manera permanente o casi permanente, ahora se conecta a través de sus móviles y suelen gastar más tiempo online que generaciones anteriores. También los adolescentes presentan una alta tasa de uso de redes sociales virtuales, por lo que se presenta una oportunidad para los distribuidores de contenido noticioso de ampliar su alcance y audiencia. Los usuarios adolescentes son los catalizadores principales en la promoción de contenidos, incluyendo noticias, a menudo en redes personales de gran tamaño. Algunas recomendaciones que se dan son: adoptar en general una actitud de móvil en primer lugar, pero en especial para aquellos proveedores de noticias que esperan llegar a los jóvenes como público objetivo, ya que los móviles son sumamente personales para quien los usa. Para los jóvenes la interactividad es atrayente por lo que podría barajarse la presentación de las noticias en forma de un juego interactivo. De aquí se desprende una posible estrategia de ingresos, si el medio tiene la capacidad de generar noticias atractivas para adolescentes y logra el patrocinio de una marca orientada a ellos, además de que también sería una forma de involucrar o comprometer a este grupo con la marca noticiosa en particular.

Por último, promover acciones de socialización de medios o social media, es decir, aprovechar que los adolescentes son adeptos a la comunicación vía SMS y el uso de redes sociales virtuales desde sus móviles, por lo que las noticias deben presentarse en un formato que permita compartirlas fácilmente, además de promover este comportamiento, incluyendo la generación de estrategias como la ganancia de puntos por hacerlo, que luego puedan ser redimidos en descuentos 
para alimentos, bebidas o distracciones orientados a ellos.

13. Llevar el mundo físico al digital usando códigos de barras en 2D (conocidos también como códigos QR). Es común que los proveedores de noticias piensen en la publicación en móviles como una extensión de la publicación en Internet, sin embargo también se presentan como un complemento para el impreso. De hecho, los móviles emergen promisorios como dispositivos que ayudarán a extender los contenidos de las publicaciones impresas en el mundo digital. Se sugiere la implementación de códigos de barras en 2D como una forma de generar valor agregado a la versión impresa. Los usuarios podrán fotografiar el mismo, el móvil lo interpretará y se visualizará la información adicional que el medio haya destinado para el artículo impreso en cuestión. El código de barra en 2D permite llevar al usuario todo tipo de contenido que no es posible tener en el impreso (bases de datos que apoyen el artículo, gráficos multimedia, foros de discusión vinculado al tema noticioso en cuestión, etcétera). Algunas sugerencias para permitir este puente entre lo móvil y lo impreso son: utilizar en los paquetes de noticias impresos códigos de barra 2D que lleve al usuario a contenidos multimedia interactivos que extiendan o complementen el paquete de prensa. El uso de códigos de barra 2D en el mercado móvil de noticias: los afiches o carteles del medio, periódicos por ejemplo, que se coloquen en espacios publicitarios de estaciones de autobuses o trenes pueden llevar un código en $2 \mathrm{D}$ de tal forma que mientras el usuario espera el servicio respectivo, pueda escanearlo con su móvil y así obtener acceso a la versión móvil, por ejemplo, o a una versión digital de las noticias en la primera plana del impreso, o incluso descargar paquetes especiales de noticias si así se ha determinado, para leerlos durante el viaje. Finalmente utilizar los códigos de barras en 2D como una extensión de la publicidad impresa, así llevar información adicional de los anunciantes al usuario a través del móvil.

14. Resaltar al público las mejores partes. Las pequeñas pantallas de los teléfonos inteligentes (así como la de los reproductores portátiles multimedia), a diferencia de las tabletas, son ventanas pequeñas para el gran consumo de grandes paquetes de contenido. Esto es un reto, por lo que podría considerarse poner en relieve o resaltarse las mejores partes del paquete noticioso en la presentación móvil. La forma más simple y más tradicional de hacerlo, es identificar las citas, párrafos, imágenes más importantes, entre otros, e incluir una lista del contenido resaltado en la tabla de contenidos o página de inicio de navegación de la versión móvil. Una técnica adicional es el desarrollo de una interfaz móvil de paquete noticioso que permita a cualquier lector subrayar o etiquetar algo que considera especial o que vale la pena compartir, abiertas a recibir calificación por parte de otros lectores desde sus móviles y luego publicar los enlaces de más alta calificación en la sección de destacados. Esta técnica puede brindar al usuario de móviles una forma de captar las partes o mensajes más importantes del paquete de una gran noticia, incluso cuando no tienen tiempo de consumir este listado por completo.

15. Facilitar a los usuarios acciones como realizar donaciones o herramientas de trabajo voluntario. El móvil se presenta como una poderosa herramienta al 
alcance de la palma de la mano que le permite al usuario tomar cualquier decisión desde cualquier lugar donde haya señal. Esto puede ser aprovechado en varios aspectos. Permite a los usuarios expresar una opinión con poder, especialmente para los paquetes de noticias en profundidad sobre temas que suscitan fuertes opiniones, una aplicación de noticias para móviles o un sitio web para móviles puede facilitar al usuario su expresión o tratar de influir en un asunto público. Motivar la ayuda de usuarios voluntarios: la presentación de informes de investigación en profundidad puede hacer que los usuarios quieran actuar directamente para solucionar el problema identificado por el periodista, por lo que, cuando se apropiado, puede incluirse un mecanismo que mediante el móvil permita la inscripción de voluntarios. Por último, facilitar las donaciones financieras: otra capacidad de los móviles es facilitar las transacciones financieras (donar dinero para apoyar a los proveedores de noticias o dar "propina" al redactor, pagar por contenidos premiun, o incluso donar dinero directamente, si es apropiado, a la organización o causa mencionada en el reporte noticioso.

Para el caso de los e-readers no se encontraron referencias bibliográficas que sugirieran funcionalidades o formas de presentación de contenido, esto puede obedecer al ecosistema cerrado propio de este dispostivo móvil. En el e-reader se intenta recrear la experiencia de leer un periódico impreso en aspectos como el color de los textos (negro sobre fondo blanco), tipo de fuente (serifada), de actualización diaria, secciones tradicionales listadas en el orden en que van en el impreso, la diposición de los bloques de texto en el despliegue de la noticia (sin espacios y con sangría al inicio de cada párrafo), con pocas imágenes, y modo sólo lectura. Hay limitaciones ya que no todo lo que aparece en el impreso pasa a la versión en el e-reader. Pueden eliminarse mapas, cuadros y gráficas; contiene menos fotografías, pueden eliminarse pie de fotos, puede no haber una jerarquización editorial, pueden eliminarse algunas columnas y contenido editorial, no se incluyen las tiras cómicas ni juegos tipo puzzle; no se incluyen los suplementos ni insertos especiales, tampoco la publicidad ni los avisos de ocasión o clasificados; y puede haber omisión parcial o total de contenido de acuerdo a los contratos firmados con las agencias de noticias. Al ser cerrada la plataforma es el propietario de la misma quien impone las pautas de diseño, forma de navegación y despliegue de la información, y los periódicos se adaptan a esta plantilla predeterminada, lo que redunda que todos ellos sean iguales en esos aspectos.

\subsection{Metodología}

Para determinar la presencia de diarios mexicanos que utilizan las plataformas móviles se recogió la información a través de una base de datos elaborada desde 2009 y actualizada hasta agosto de 2012. Se revisó en cada periódico registrado en el Padrón General de Medios Impresos, de la Secretaría de Gobernación para verificar cuántos, de 
los 301 diarios inscritos en él y con acceso a un sitio web, proporcionaban algún vínculo móvil entre ellos y sus lectores.

Se buscó en cada sitio web si proporcionaban vínculo a través de aplicaciones para iPhone, iPad, BlackBerry, PlayBook, familia Samsung Galaxy y otras tabletas y teléfonos inteligentes con Android, Nokia Lumia y otros teléfonos inteligentes con Windows Phone, teléfonos inteligentes con Symbian, Kindle, etcétera. De esta manera se podría ver si ha habido una implementación del periodismo digital en los diarios mexicanos desde el año 2009 en que se hizo una primera observación; también se pudo ver de qué forma han adoptado las plataformas móviles de los diarios mexicanos y el crecimiento que han presentado los diarios mexicanos en Internet, en algunos casos no solo para complementar las ediciones impresas, sino también como una opción para desarrollar el periodismo exclusivamente en línea.

\subsection{Hallazgos y reflexiones}

De acuerdo al análisis realizado mediante la observación y la medición de la cantidad de diarios que ofrecen a sus lectores la posibilidad de acceder a ellos mediante aplicaciones móviles, es importante hacer notar que en el análisis realizado en 2009, ninguna publicación -de 314 contabilizadas- contaba con la posibilidad de acceder a alguna aplicación que descargara material en algún teléfono celular, todos los contenidos estaban hechos para ser vistos a través de la red pues la penetración de las plataformas móviles en México ha sido lenta; lo condujo, sin embargo, al desarrollo del aspecto de contacto interactivo entre los diarios y los lectores a través de blogs, foros, chats, SMS, comentarios, encuestas, correos electrónicos, tests y sondeos, tal como se presenta en la gráfica en la cual se representan aquellos que tuvieron mayor presencia en la red de acuerdo al portal de medición Alexa.

\begin{tabular}{|l|l|}
\hline \multicolumn{2}{|c|}{ PERIÓDICOS CON MAYOR PENETRACIÓN EN INTERNET EN 2009 } \\
\hline \multicolumn{1}{|c|}{ Diario } & \multicolumn{1}{c|}{ Dirección electrónica } \\
\hline EL UNIVERSAL & $\underline{\text { www.eluniversal.com.mx }}$ \\
\hline REFORMA & $\underline{\text { www.reforma.com }}$ \\
\hline LA JORNADA & $\underline{\text { www.jornada.unam.mx }}$ \\
\hline MILENIO & $\underline{\text { www.milenio.com }}$ \\
\hline $\begin{array}{l}\text { EL NUEVO EXCÉLSIOR (actualmente } \\
\text { Excélsior) }\end{array}$ & $\underline{\text { www.nuevoexcelsior.com.mx }}$ \\
\hline
\end{tabular}

Para 2012, de un total de 301 periódicos, solo 54 publicaciones añadieron opciones en sus sitios web para diferentes tipos de dispositivos (algunas de estas publicaciones pertenecen a grupos editoriales -Milenio, Reforma, Zócalo de Satillo-). Entre las aplicaciones utilizadas se encuentran aquellas para los aparatos que cuenten con sistemas Android y Symbian o aquellas específicas para iPad, iPhone, BlackBerry -incluído 
PlayBook-, y Kindle, así como para cualquier otro dispositivo móvil.

Las publicaciones que cuentan con un mayor número de aplicaciones son El Universal y El País (aunque el sitio web redirecciona al sitio del diario español); asimismo, los diarios pertenecientes al Grupo Reforma también presentan sus contenidos a través paywall, el resto lo hace de manera gratuita para cualquier lector.

Aunque la adopción de dispositivos y plataformas móviles ha sido en tiempo récord, comparado con la incorporación de los diarios impresos a la web.

En 2011, eran más de 30 diarios generalistas que usaban las plataformas móviles, de un total de 10 formatos disponibles en ese momento. En ambas observaciones (2011-2012) quedó en evidencia que la prensa mexicana no ha adoptado a todas las plataformas móviles por igual pues se encontró una gran diferencia entre la cantidad de aplicaciones y la preferencia por ofrecer una u otra al público; las preferidas son iOS para iPhone y BlackBerry OS, lo cual manifiesta la apuesta por el uso de los contenidos periodísticos para teléfonos inteligentes.

El resto de los periódicos -247- no apuestan por ninguna plataforma móvil, solo por la presentación de contenido web, algo que deberían replantearse, pues la mayoría presenta un diseño anticuado; otras no optan siquiera por usar las redes sociales para compartir la información y difundirla por la red, lo cual nos lleva a pensar en la obsolescencia en que están cayendo las publicaciones diarias.

Futuros estudios a partir de ver que la cantidad de diarios que han adoptado las plataformas móviles va en crecimiento pueden plantearse en torno al análisis de los contenidos que ofrecen esas plataformas, si en realidad son novedosas u ofrecen valor añadido a lo que el lector pueda encontrar en un sitio web; además puede observarse la estabilidad de la plataforma, la actualización. También puede estudiarse la adopción por parte de los usuarios, las edades, las preferencias por una u otra plataforma; el crecimiento en determinados puntos geográficos del país, etcétera. Pues hay que tomar en cuenta que el crecimiento en la oferta que las editoras den a sus lectores redunda en beneficio a través de publicidad, estilos de mercadotecnia, fidelización y otros elementos de promoción y ganancias que cualquier otra empresa que tenga presencia en la red pueda detectar y utilizar.

Si en la actualidad la llamada crisis del periodismo está obligando a cerrar publicaciones, optar por las plataformas digitales es una opción a la que están recurriendo en diversos países del mundo, por qué en México no se está tomando en cuenta esta opción, es una propuesta acorde al crecimiento que Internet y la penetración que las herramientas móviles están teniendo entre la población (se incentiva así un modelo de negocio). El público encuentra así nuevos soportes de distribución de contenido que se suman al impreso (web, móvil, SMS).

La complicación que supone la creación de software para desarrollar aplicaciones en los diversos sistemas operativos y que exige el tener desarrolladores especialistas en cada una para que las creen y las mantengan puede ser un obstáculo económico para que se añadan más empresas periodísticas a esta nueva opción para el lector. Además los costos 
que supone el pago a los propietarios de las diversas plataformas.

Además de esto, debe pensarse en una calidad del contenido que se publique en cada una de estas plataformas pues hay que actualizar la información, mantener el diseño y evitar los errores de programación, además de estar al pendiente de los cambios en la velocidad de conexión que pueda tener el lector.

Y es que como señala Robinson (2006), la participación en la red a través de las herramientas adecuadas crea una forma de periodismo abierto con múltiples voces (69) y representa una forma de expresión que promueve la colaboración -voluntaria, asíncrona y pública de los usuarios en la comunicación (Larrondo, 2005) hecho que no debe de pasarse de largo en México en donde siempre se ha respondido de forma amplia a las nuevas opciones que en materia de tecnología y de contenidos se han desarrollado en otros países (más desarrollados), y en donde la investigación y las condiciones sociales han permitido que se instalen con respuestas también positivas y en aras de mejorar, en este caso, los medios de comunicación ya establecidos.

En México, la investigación en torno al periodismo digital da un amplio margen para que se destaque también la importancia que este debe (y está) cobrar en la sociedad.

Los resultados nos permiten detectar que el periodismo en México tiene un camino bastante prometedor si se continúa adoptando la tecnología de vanguardia y si se ofrecen valores agregados en las versiones digitales; pues el crecimiento de la población que tiene acceso a la red en el país va aumentando considerablemente cada año.

\subsection{Referencias bibliográficas}

Asociación Mexicana de Internet. AMIPCI. (2012) Hábitos de los usuarios de Internet en México. Recuperado de http://www.amipci.org.mx/?P=esthabitos

Canavilhas, J. (2011) “El nuevo economista mediático”. Index Comunicación, 1, 13-24. Recuperado de http://journals.sfu.ca/indexcomunicacion/index.php/indexcomunicacion/article/viewF ile $/ 4 / 7$

comScore. Futuro Digital México 2012. (2012, agosto 7) Recuperado de http://www.comscore.com/esl/Press_Events/Presentations_Whitepapers/2012/Futur o_Digital_Mexico

Digital News Test Kitchen. (2010). "In-depth news for smartphones". University of Colorado, Boulder School of Journalism \& Mass Communication. Recuperado de http://testkitchen.colorado.edu/projects/reports/smartphone/

Kittler, F. (1996, 30 de julio). "The history of communication media". Ctheory. Recuperado de http://www.ctheory.net/articles.aspx?id=45 iabMéxico. Estudio de Consumo de Medios Digitales en México 2011. Recuperado de 
http://www.iabmexico.com/node/9186

Larrondo Ureta, A. (2005) "Presencia del formato weblog en los cibermedios: una aproximación a sus usos y funciones". En Revista Latina de Comunicación Social. Núm 60. II época, La Laguna (Tenerife). Recuperado de http://www.ull.es/publicaciones/latina/200539larrondo.pdf

Parra, D. (2008). "Ciberperiodismo móvil: el peso específico de la cuarta pantalla en el panorama informativo internacional". Re-presentaciones: periodismo, comunicación y sociedad, 2(4),73-91. Recuperado de http://dialnet.unirioja.es/servlet/fichero_articulo? codigo $=2990230 \&$ orden $=0$

Robinson, S. (2006): “The mission of the j-blog: Recapturing journalistic authority online". En Journalism, vol. 7, no. 1, 65-83.

Speckmann, B. (2008). “The Android mobile platform”. Eastern Michigan University. Recuperado de http://www.emich.edu/compsci/projects/Master_Thesis__Benjamin_Speckmann.pdf

Valverde, E. \& Aguado, J. (2010). "Dispositivos móviles y convergencia digital en los grupos de comunicación españoles: la perspectiva de los profesionales". II Congreso Internacional AE-IC: Comunicación y desarrollo en la era digital. Recuperado de http:/ www.aeic.org/malaga2010/upload/ok/95.pdf

Vavrus, J. (2011, 29 de junio). “¿Son los e-readers el futuro de las noticias?”. Blog Periodismo de las Américas. Recuperado de http://knightcenter.utexas.edu/es/blog/ $\% \mathrm{C} 2 \% \mathrm{BF}$ son-los-e-reader-el-futuro-de-las-noticias 


\section{Contraportada}

Los años 2006 y 2007 marcaron un giro importante en materia de comunicaciones digitales, a diez años de la apertura de la Web al ámbito comercial y privado: se produjo el "despegue" de las redes sociales y, casi simultáneamente la comercialización de los llamados "teléfonos inteligentes" o "smartphones" que, poco a poco fueron incluyendo una cámara fotográfica. Hace ya años que la prensa se debate entre la forma impresa y la forma digital en la Web, debiendo ajustar su "modelo de negocio". Éste nuevo recurso está afectando ahora más directamente el trabajo de los periodistas tanto como el de los editores que se ven enfrantados a nuevas modalidades de lectura. El presente volúmen recoge algunos trabajos que dan cuenta de esta nueva realidad.

\section{Los Autores}

Sonia González Molina es profesora ayudante del Departamento de Ciencias de la Comunicación de la Universitat Jaume I (UJI) de Castellón, donde imparte las asignaturas de Cibeperiodismo y Periodismo institucional. Sus líneas de investigación se centran en la convergencia comunicativa, los gabinetes de prensa, la comunicación institucional, y el periodismo de servicio.

João Canavilhas es licenciado en Comunicação Social por la Universidade da Beira Interior (Portugal) y doctor por la Universidad de Salamanca. (España). Actualmente es profesor en la Universidade da Beira Interior donde imparte clases de webperiodismo, periodismo radiofónico e infografia multimedia. Además de las funciones docentes, es director del Mestrado em Jornalismo, vicepresidente del Centro de Investigación Labcom-UBI y director del periódico online URBI, el primer periódico universitario portugués en la web.

Miguel Carvajal Prieto (PhD, 2006) es profesor de Periodismo en la Universidad Miguel Hernández (UMH) de Elche (España). Ha sido investigador visitante en el Donald McGannon Communication Research Center de Fordham University (Nueva York) durante 2010. Su ámbito de estudio se centra en la economía de los medios, en particular trabaja desde hace varios años sobre nuevos modelos de financiación del periodismo digital. Es director del Máster de Innovación en Periodismo de la UMH.

Claudia Alicia Lerma Noriega obtuvo el grado doctoral en Ciencias de la Comunicación en la Universidad Complutense de Madrid. Actualmente es profesora del Tecnológico de Monterrey. Ha participado como maestra invitada en varias universidades, además pertenece a Consejos Editoriales de algunas publicaciones internacionales. Es autora del libro "Documentos electrónicos" y del ebook "Periodismo Efectivo en la Red". Su línea de investigación se centra en el desarrollo del periodismo digital en México, la usabilidad web, y la enseñanza del periodismo digital.

Tania Lucía Cobos Cobos es comunicadora social y periodista, especialista en periodismo electrónico. Obtuvo su maestría en Ciencias en Comunicación del Tecnológico de Monterrey y está admitida en el Doctorado en Comunicación y Periodismo de la Universidad Autónoma de Barcelona. Actualmente es directora y jurado evaluador de trabajos de grado en la Maestría en Comunicación Digital de la Universidad Pontificia Bolivariana (Colombia). 